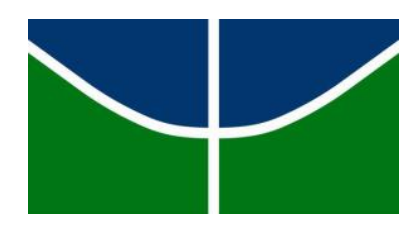

Universidade de Brasília - UNB

Centro de Estudos Avançados Multidisciplinares - CEAM

Programa de Pós-Graduação em Desenvolvimento, Sociedade e

Cooperação Internacional - PPGDSCI

\title{
O CONSUMO NA ESTRATÉGIA DE DESENVOLVIMENTO SUSTENTÁVEL BRASILEIRA
}

Humberto Santana Junior

Dissertação de Mestrado

\author{
Brasília - DF \\ 2016
}




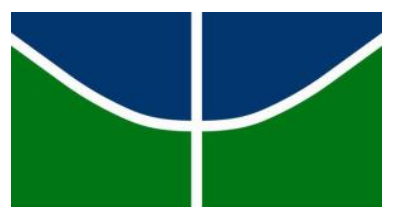

Universidade de Brasília - UNB

Centro de Estudos Avançados Multidisciplinares - CEAM

Programa de Pós-Graduação em Desenvolvimento, Sociedade e

Cooperação Internacional - PPGDSCI

\title{
O CONSUMO NA ESTRATÉGIA DE DESENVOLVIMENTO SUSTENTÁVEL BRASILEIRA
}

\author{
Humberto Santana Junior
}

Dissertação de Mestrado apresentada ao Programa de Pós-Graduação em Desenvolvimento, Sociedade e Cooperação Internacional, do Centro de Estudos Avançados Multidisciplinares da Universidade de Brasília, como requisito para obtenção do título de Mestre em Desenvolvimento, Sociedade e Cooperação Internacional sob orientação da Professora Dra. Doriana Daroit.

Brasília - DF

2016 


\title{
O CONSUMO NA ESTRATÉGIA DE DESENVOLVIMENTO SUSTENTÁVEL BRASILEIRA
}

\begin{abstract}
Dissertação de Mestrado apresentada ao Programa de Pós-Graduação em Desenvolvimento, Sociedade e Cooperação Internacional do Centro de Estudos Avançados Multidisciplinares da Universidade de Brasília como requisito para obtenção do título de Mestre em Desenvolvimento, Sociedade e Cooperação Internacional sob orientação da Professora Dra. Doriana Daroit.
\end{abstract}

Brasília, 04 de abril de 2016.

\section{COMISSÃO EXAMINADORA}

\section{Professora Dra. Doriana Daroit}

Orientadora - Universidade de Brasília

\section{Professor Dr. Alexandre Maduro-Abreu}

Examinador Externo - Departamento de Administração - Universidade de Brasília

Professor Dr. Luiz Fernando Bessa

Examinador Interno - Universidade de Brasília

Professora Dra. Magda de Lima Lúcio

Suplente - Universidade de Brasília 


\section{FICHA CATALOGRÁFICA}

SANTANA JUNIOR, Humberto.

O consumo na estratégia de desenvolvimento sustentável brasileira. / Humberto Santana Junior.

Brasília, 2016.

Dissertação de Mestrado. Centro de Estudos Avançados Multidisciplinares. Universidade de Brasília, Brasília.

Programa de Pós-Graduação em Desenvolvimento, Sociedade e Cooperação Internacional 
Dedico este trabalho à minha família que sempre me apoiou em todas as minhas jornadas, em especial, à minha avó Jorgelina (in memoriam). 


\section{AGRADECIMENTOS}

Agradeço aos meus pais, Humberto e Maria, que estiveram sempre me apoiando para realizar este e outros trabalhos;

À minha irmã, Jamile, que sempre me deu forças para continuar quando eu mais precisei;

À Professora Doriana, por aceitar me orientar e por sua dedicação para a realização deste trabalho;

Aos meus amigos, que acompanharam todo o meu trajeto durante esses dois anos de mestrado;

Aos colegas de turma, que sempre apontavam bons comentários e boas discussões durante as aulas;

Aos demais professores do mestrado, por seus ensinamentos e suas aulas que trouxeram mais indagações a realização desta dissertação;

Aos colegas da Revista Perspectivas do Desenvolvimento, que enfrentaram diversos obstáculos, mas nunca deixaram de correr atrás do sucesso da mesma;

Aos diplomatas Vicente de Azevedo Araújo Filho e Vicente Amaral Bezerra, por me proporcionarem grandes ensinamentos e inspirações ao longo das reuniões na Missão do Brasil junto às Nações Unidas;

Aos entrevistados, Haroldo Machado Filho, Mario Mottin, Ian Ramalho Guerriero, Raquel Breda dos Santos, Renato Rosernberg e Fabio Larotonda, por aceitarem responder aos meus questionamentos para melhor compreensão do meu objetivo. 
"A menos que modifiquemos a nossa maneira de pensar, não seremos capazes de resolver os problemas causados pela forma como nos acostumamos a ver o mundo".

(Albert Einstein) 


\section{RESUMO}

Desde a Primeira Revolução Industrial, a sociedade em que vivemos vem passando por enormes transformações. O modelo de desenvolvimento econômico-industrial predominante vem alimentando ao longo dos anos o desejo e a necessidade por um consumo desenfreado, seja pelo incentivo da mídia ou pelo próprio modo de vida urbano. A exploração de recursos naturais, advinda mais fortemente com a industrialização, para satisfazer o desejo de consumo das pessoas, traz vários impactos negativos ao meio ambiente levando ao esgotamento e deterioração da disponibilidade desses recursos e ao aumento exponencial e sem limites do consumo de matérias e energia transformadas em mercadorias. A capacidade do planeta frente às necessidades humanas e as práticas insustentáveis de consumo e produção está se esgotando e o desenvolvimento sustentável aparece como o caminho para a integração de interesses sociais e econômicos com as possibilidades e limites da natureza. Neste sentido, o crescimento econômico deve ser orientado para que suas políticas públicas estabeleçam um maior vínculo entre o meio ambiente e o desenvolvimento. $O$ enfrentamento dos impactos ambientais requer uma mudança estrutural na forma como o sistema econômico opera e este dilema entre crescimento econômico e desenvolvimento sustentável está presente no contexto brasileiro. Neste sentido, a presente dissertação tem a finalidade de tentar compreender a problemática do sistema produtivo que requer o tratamento de complexas relações entre as demandas econômicas sociais e ambientais em diferentes âmbitos governamentais e setoriais. $O$ objetivo deste estudo é, portanto, discutir os resultados obtidos pelas políticas públicas brasileiras sobre os indicadores de desenvolvimento e consumo. Para responder a este objetivo, a metodologia do trabalho apresenta um estudo de natureza qualitativa sobre a estratégia de desenvolvimento sustentável brasileira a partir da sua relação com o consumo. Os principais resultados indicam que as políticas públicas brasileiras estão cada vez mais levando em consideração as questões ambientais, porém ainda necessitam de maior atenção, pois antes de incentivar um consumo desenfreado, deveriam buscar formas de equilibrar a prática do consumo com os limites e as possibilidades da natureza.

Palavras-chave: Consumo; Desenvolvimento Sustentável; Meio Ambiente; Crescimento Econômico; Políticas Públicas. 


\begin{abstract}
Since the First Industrial Revolution, the society we live in has undergone enormous changes. The prevailing economic and industrial development model has nurtured over the years the desire and need for unbridled consumption, either by the media encourage or by the urban way of life. The exploitation of natural resources, arising more strongly with industrialization, to satisfy consumer desire of the people, has several negative environmental impacts leading to depletion and deterioration of the availability of those resources and the exponential increase and unlimited consumption of materials and energy transformed into commodities. The capacity of the planet to human needs and unsustainable consumption and production practices is running out and sustainable development appears as the way for the integration of social and economic interests with the possibilities and limits of nature. In this sense, economic growth should be oriented so that their public policies establish a stronger link between the environment and development. Addressing environmental impacts requires a structural change in the way the economic system operates and this dilemma between economic growth and sustainable development is present in the Brazilian context. In this sense, this thesis is intended to try to understand the problems of the production system that requires the treatment of complex relationships between environmental and social economic demands in different government and industry levels. The aim of this study is, therefore, to discuss the results achieved by the Brazilian public policies on the development of indicators and consumption. To meet this goal, the methodology of work presents a qualitative study on Brazil's sustainable development strategy from its relationship with the consumer. The main results indicate that the Brazilian public policies are increasingly taking into account environmental issues, but still need more attention, because before encourage unbridled consumption, should seek ways to balance the practice of consumption with the limits and possibilities from nature.
\end{abstract}

Keywords: Consumption; Sustainable Development; Environment; Economic Growth; Public Policy. 


\section{LISTA DE TABELAS}

Tabela 1 - Consumo de petróleo e gás natural no Brasil 


\section{LISTA DE QUADROS}

Quadro 01 - Relação de Entrevistados 


\section{LISTA DE GRÁFICOS}

Gráfico 1 - Número de famílias beneficiadas pelo Programa Bolsa Família

Gráfico 2 - Evolução do consumo das famílias

Gráfico 3 - Consumo Mensal Familiar (período 2008 a 2009)

Gráfico 4 - Evolução da capacidade de energia eólica

Gráfico 5 - Pessoas com acesso a instalações de esgoto em domicílios particulares

Gráfico 6 - Cidades com Coleta Seletiva 


\section{LISTA DE ABREVIATURAS}

A3P Agenda Ambiental da Administração Pública

BACEN Banco Central Brasileiro

BNDES Banco Nacional de Desenvolvimento

CAR Cadastro Ambiental Rural

CATMAT Catálogo de Materiais

CEMADEN Centro de Monitoramento e Alertas de Desastres Naturais

CGPCS Comitê Gestor Nacional de Produção e Consumo Sustentáveis

CsF Ciências sem Fronteiras

ECO-92 Conferências das Nações Unidas sobre o Ambiente e o Desenvolvimento

ENCTI Estratégia Nacional de Ciência, Tecnologia e Informação

FIB Felicidade Interna Bruta

FMI Fundo Monetário Internacional

FNDE Fundo Nacional de Desenvolvimento da Educação

IBGE Instituto Brasileiro de Geografia e Estatística

IDH Índice de Desenvolvimento Humano

IPEA Instituto de Pesquisa Econômica Aplicada

IRI Índice de Riqueza Inclusiva

MCTI Ministério da Ciência, Tecnologia e Informação

MDIC Ministério do Desenvolvimento, Indústria e Comércio Exterior

MMA Ministério do Meio Ambiente

MPOG Ministério do Planejamento, Orçamento e Gestão

ODS Objetivos de Desenvolvimento Sustentável

ONU Organização das Nações Unidas

PAC Programa de Aceleração do Crescimento

PBQP-H Programa Brasileiro de Qualidade e Produtividade do Habitat

PDE Plano de Desenvolvimento da Educação 
PEAAF Programa de Educação Ambiental e Agricultura Familiar

PIB Produto Interno Bruto

PNRS Política Nacional de Resíduos Sólidos

PNUD Programa das Nações Unidas para o Desenvolvimento

PNUMA Programa das Nações Unidas para o Meio Ambiente

PPA Plano PluriAnual

PPCS Plano de Ação para Produção e Consumo Sustentáveis

Pronatec Programa Nacional de Acesso ao Ensino Técnico e Emprego

ProNEA Programa Nacional de Educação Ambiental

Selo A3P Selo de Sustentabilidade na Administração Pública

SISG Órgãos do Sistema Integrado de Administração de Serviços Gerais 


\section{SUMÁRIO}

\section{LISTA DE TABELAS}

LISTA DE QUADROS

LISTA DE GRÁFICOS

LISTA DE ABREVIAMENTOS E SIGLAS

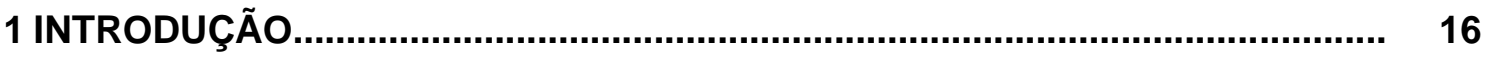

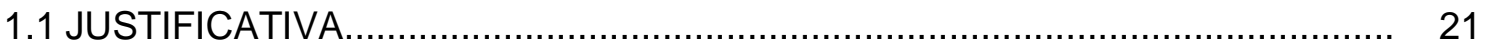

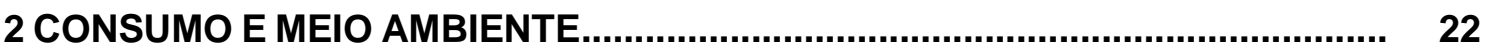

2.1 A PRODUÇÃO E CONSUMO DE BENS E SERVIÇOS COMO FONTE DINÂMICA ECONÔMICA SOCIAL .............................................................................. 28

2.2 CONSUMO, MEIO AMBIENTE E DESENVOLVIMENTO .............................. 34

2.3 CONSUMO, MEIO AMBIENTE E POLÍTICAS PÚBLICAS.............................. 39

3 MÉTODO DE PESQUISA ................................................................................. 44

4 EXPERIÊNCIA BRASILEIRA NA RELAÇÃO ENTRE CONSUMO E

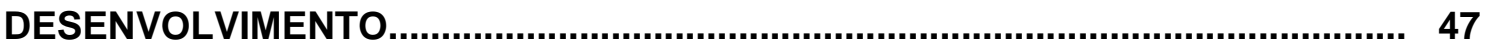

4.1 O AUMENTO DA RENDA DA POPULAÇÃO ATRAVÉS DE PROGRAMAS DE TRANSFERÊNCIA DE RENDA............................................................ 55

4.2 RECURSOS NATURAIS ........................................................................ 60

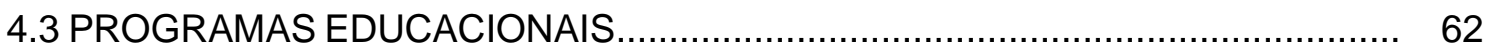

4.4 GERAÇÃO DE RESÍDUOS.................................................................. 64

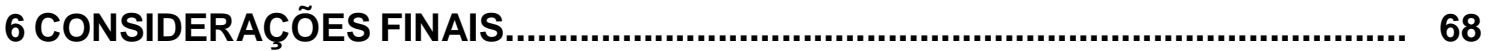

REFERÊNCIAS BIBLIOGRÁFICAS................................................................. 72

APÊNDICE 


\title{
1 INTRODUÇÃO
}

\begin{abstract}
"A forma como vivemos e nossos valores são a expressão da sociedade na qual vivemos. $E$ a gente se agarra a isso. Não digo isso por ser presidente do Uruguai hoje. Pensei muito sobre isso. Passei mais de dez anos na solitária. Teve um tempo que estive 7 anos sem ler nem sequer um livro. Tive muito tempo para pensar. E descobri o seguinte. Ou você é feliz com pouco, com pouca bagagem, pois a felicidade está em você, ou não consegue nada. Isso não é a apologia da pobreza, mas a apologia da sobriedade. Só que inventamos uma sociedade de consumo, consumista e a economia tem de crescer ou acontece uma tragédia. Inventamos uma montanha de consumos supérfluos. Compra-se e descarta-se. Mas o que se gasta é tempo de vida. Quando compro algo, ou você compra algo, não pagamos com dinheiro, pagamos com o tempo de vida que tivemos que gastar para ter aquele dinheiro. Mas tem um detalhe: a única coisa que não se pode comprar é a vida. A vida se gasta. E é lamentável desperdiçar a vida para perder a liberdade" (José Mujica, 2015).
\end{abstract}

A fala do ex-presidente do Uruguai, José Mujica, no documentário Human de Yann Arthus-Bertrand (2015), demonstra o momento que a sociedade atual vem enfrentando para lidar com o aumento do consumo desencandeado desde a Primeira Revolução Industrial, na qual a exploração de recursos naturais, advinda mais fortemente com a industrialização, começou a trazer à tona a discussão sobre os impactos causados ao meio ambiente e a forma como eles deveriam ser tratados.

Segundo Lombardo (2007), estamos vivenciando um elevado grau de degradação ambiental desencadeado pelas características intrínsecas do desenvolvimento econômico-industrial alimentado pelas relações contraditórias de necessidade e consumo do mundo contemporâneo. Para a autora, os hábitos de consumo exigidos e alicerçados pela mídia englobam esferas do cotidiano, criando desigualdades sociais avassaladoras cuja solução orientada por políticas públicas é difícil de ser encontrada.

A sociedade moderna é constantemente incentivada pela mídia e pelo próprio modo de vida urbano a um consumo desenfreado, com a aquisição de artigos supérfluos e descartáveis. O status da pessoa passa a ser medido pelo que ela consome ao invés do que poderia ser necessário e útil à sua vida (CORTEZ; ORTIGOZA, 2007).

Segundo Berríos (2007), a sociedade urbano-industrial sofre uma transformação que a diferencia das sociedades tradicionais, na qual deixa de ser homogênea e aparece fragmentada, bipolarizada, dividida:

entre o restrito setor abastado, por um lado, mostrando elevado poder de compra, indutor e seguidor assíduo dos padrões comportamentais impostos artificialmente desde os principais centros mundiais de produção e consumo, marcados pela excessiva demanda de tudo o que os mercados oferecem, enquanto, no outro extremo, situa-se o vastíssimo setor de indivíduos pobres, impedidos economicamente, muitas vezes, de satisfazer as necessidades mais básicas, sem acesso aos benefícios da modernidade globalizada, desconectados da 
realidade dos países centrais. Entre ambas, encontram-se as dinâmicas camadas médias, inconformadas com a situação em que estão, sempre procurando imitar - geralmente com sucesso relativo os padrões comportamentais e de consumo da classe rica, lutando para não descer socialmente à dos pobres, suportando as pressões vindas de ambas as direções (BERRÍOS, 2007, p. 87).

Esta expressão da sociedade atual, de economia capitalista, demonstra a grande problemática ambiental: o esgotamento e a deterioração da disponibilidade de recursos naturais e o aumento exponencial e sem limite do consumo de matérias e energia transformadas em mercadorias. Estas contradições podem conduzir a um grande colapso e à autodestruição tanto do próprio sistema capitalista como sistema de ordenação socioeconômica, mas também de toda a humanidade (BERRíOS, 2007).

A capacidade do planeta frente às necessidades humanas e práticas insustentáveis de produção e de consumo começa a ganhar maior relevância e maior atenção quando o tema é elencado como uma das prioridades identificadas na primeira Conferência das Nações Unidas sobre o Meio Ambiente e o Desenvolvimento, realizada em Estocolmo, em 1972.

Uma nova maneira de perceber soluções para os problemas globais, que não se reduzem apenas à degradação ambiental, mas incorporam também as dimensões sociais, políticas e culturais, é revelada com o desenvolvimento sustentável. A integração de interesses sociais e econômicos com as possibilidades e os limites que a natureza define é um caminho a ser percorrido para o desenvolvimento. Neste sentido, o desenvolvimento sustentável é concebido como um novo paradigma ao relacionar as aspirações coletivas de paz, liberdade, melhores condições de vida e um meio ambiente saudável (CAMARGO, 2003).

O novo paradigma, de acordo com Montibeller-Filho (2001), pressupõe um conjunto de sustentabilidades (eficiência econômica, eficácia social e ambiental) que se atingidas levam ao desenvolvimento sustentável.

O conceito de sustentabilidade é crucial para a transição de um novo modelo de desenvolvimento sustentável baseado na modificação dos paradigmas de produção e consumo vigentes. Segundo os autores Morais e Costa (2010), por sustentabilidade entende-se diferentes dimensões que se inter-relacionam:

como a ecológica (estoque e uso de recursos naturais utilizados na produção e no consumo); ambiental (capacidade da natureza de absorver e recuperar-se das agressões); demográfica (à luz das duas anteriores, analisar o impacto da dinâmica demográfica); cultural (criação/preservação de valores e práticas que induzam novos padrões de integração nacional, regional e local); social (melhoria da qualidade de vida e justiça distributiva); política (possibilidades de construção participativa da cidadania e de um novo projeto de desenvolvimento) e 
institucional (como todos esses aspectos se refletem na construção de novas institucionalidades sociais, políticas e econômicas (MORAIS, COSTA, 2010, p. 15).

Segundo Sachs (2009), existem oito critérios apontados para a sustentabilidade do desenvolvimento sustentável:

1 - Social: alcance de um patamar razoável de homogeneidade social; distribuição de renda justa; emprego pleno e/ou autônomo com qualidade de vida decente; igualdade no acesso aos recursos e serviços sociais;

2 - Cultural: mudanças no interior da continuidade (equilíbrio entre respeito à tradição e inovação); capacidade de autonomia para elaboração de um projeto nacional integrado e endógeno; autoconfiança combinada com abertura para o mundo;

3 - Ecológica: preservação do potencial do capital natural na sua produção de recursos renováveis; limitar o uso dos recursos não-renováveis;

4 - Ambiental: respeitar e realçar a capacidade de autodepuração dos ecossistemas naturais;

5 - Territorial: configurações urbanas e rurais balanceadas; melhoria do ambiente urbano; superação das disparidades inter-regionais; estratégias de desenvolvimento ambientalmente seguras para áreas ecologicamente frágeis;

6 - Econômico: desenvolvimento econômico intersetorial equilibrado; segurança alimentar; capacidade de modernização contínua dos instrumentos de produção; razoável nível de autonomia na pesquisa científica e tecnológica; inserção soberana na economia internacional;

7 - Política (nacional): democracia definida em termos de apropriação universal dos direitos humanos; desenvolvimento da capacidade do Estado para implementar o projeto nacional em parceria com todos os empreendedores; nível razoável de coesão social;

8 - Política (internacional): eficácia do sistema de prevenção de guerras da ONU na garantia da paz e na promoção da cooperação internacional; um pacote Norte-Sul de co-desenvolvimento baseado no princípio da igualdade; controle institucional efetivo do sistema internacional financeiro e de negócios; controle institucional efetivo de aplicação do Princípio da Precaução na gestão do meio ambiente e dos recursos naturais; prevenção das mudanças globais negativas; proteção da biodiversidade biológica; gestão do patrimônio global; sistema efetivo de cooperação cientifica e tecnológica internacional e eliminação parcial do caráter de commodity da ciência e tecnologia.

O desenvolvimento sustentável, ao trazer a dimensão da sustentabilidade ambiental à tona, baseada no duplo imperativo ético de solidariedade sincrônica com a geração atual e a solidariedade diacrônica com as gerações futuras, nos impele a buscar 
soluções que resolvam os custos negativos sociais e ambientais e ainda assim, não deixem de obter um crescimento econômico esperado (SACHS, 2008).

A solidariedade sincrônica induz a problemática de acesso equitativo aos recursos e a redistribuição dos mesmos enquanto a solidariedade diacrônica obriga a alargar o horizonte temporal para além do tempo do economista, provocando forte alteração ao nível do instrumental habitualmente utilizado na arbitragem entre o presente e o futuro (SACHS, 1986).

O enfrentamento dos impactos ambientais requer uma mudança estrutural na forma como o sistema econômico opera: a expansão acelerada da produção e do consumo, bases do crescimento econômico, este último entendido como vital para a manutenção ou obtenção de níveis considerados adequados ao bem-estar das populações de diferentes países, pode entrar em choque com os impactos ambientais gerados pelo sistema produtivo.

No Brasil, este dilema entre crescimento econômico e desenvolvimento sustentável expressa-se fortemente, dado que, como país em desenvolvimento, o mesmo precisa firmar-se no sistema capitalista via crescimento econômico, mas como detentor de extensos e diversos recursos naturais os mesmos podem se constituir como sustentação de um modelo de desenvolvimento menos poluente e socialmente mais justo.

O Brasil demonstra preocupar-se com a questão do consumo sustentável ao longo de sua história com a realização de iniciativas, workshops e eventos sobre o tema. $\mathrm{A}$ Agenda Ambiental da Administração Pública é um importante instrumento para a forma como o governo atua levando em consideração o meio ambiente. No cenário internacional, o país é presença garantida na discussão do assunto, tanto que foi responsável por sediar dois importantes eventos internacionais: a ECO-92 e a Rio+20. Recentemente, o governo criou o Plano de Ação para Produção e Consumo Sustentáveis com vistas a guiar suas ações de maneira mais sustentável.

A presente dissertação pretende problematizar a forma como o governo brasileiro vem formulando sua estratégia de desenvolvimento levando em consideração a questão do consumo sustentável. Para isso, será abordado um debate em torno do desenvolvimento sustentável e o crescimento econômico desencadeado pelo sistema capitalista atual que promove um aumento do consumo e consequentemente um aumento nos impactos ambientais.

O crescimento econômico, elemento essencial de qualquer política de Estado, deve ser reorientado para que suas políticas públicas passem a estabelecer uma maior conexão com o meio ambiente e o desenvolvimento sustentável. O governo brasileiro, em seus documentos oficiais, especialmente os relatórios de avaliação dos PPAs, vem 
definindo sua estratégia de desenvolvimento como fundamentada no consumo de massa como base para um processo inclusivo. Este resultado seria obtido pela ampliação da produção e do investimento, por consequência dos empregos, sendo a produção e a tecnologia orientadas para a sustentabilidade (MPOG, 2014).

Para que o crescimento do país se traduza em bem-estar para a maioria da população é necessário a coordenação das ações do governo para estimular a dinâmica econômica centrada na inclusão social, ampliando as escalas de produção, aumentando a produtividade e contribuindo para o crescimento econômico sustentável. Neste sentido, o desenvolvimento significa que o uso de recursos naturais para geração de riqueza e renda não deve se dissociar da promoção da qualidade de vida e da sustentabilidade.

Segundo o Relatório de Avaliação do PPA 2012-2015, a estratégia para os setores produtivos deve procurar assegurar a convergência entre as políticas de estímulo à demanda e de apoio à oferta. No que se refere a demanda, observa-se a promoção do emprego formal e da atividade empreendedora, assim como a valorização da renda do trabalho e sua melhor distribuição. No que se refere a oferta, busca-se fortalecer as bases institucionais, fomentar a inovação tecnológica, o adensamento da cadeia produtiva, além de garantir o acesso ao crédito e condições propícias ao investimento produtivo.

No entanto, este modelo de promoção do desenvolvimento é questionado por uma expressiva quantidade de autores, como Jean Baudrillard, Zygmunt Bauman, Pierre Bourdieu, Clóvis Cavalcanti, Fátima Portilho, entre outros. Isto coloca questões importantes do ponto de vista do modelo de desenvolvimento e das políticas públicas implementadas para sua promoção.

A problemática do sistema produtivo, que se manifesta tanto globalmente como localmente, requer o tratamento das complexas relações entre demandas econômicas sociais e ambientais em diferentes âmbitos governamentais e setoriais. A pergunta que norteou a dissertação durante seu processo de elaboração foi: Como estas demandas vêm sendo compatibilizadas no Brasil no seu processo de desenvolvimento, considerando suas políticas públicas orientadoras?

Para responder a esta pergunta, ao longo trabalho buscou-se identificar as políticas públicas com foco em desenvolvimento e consumo e seus resultados, buscando discutir a relação entre desenvolvimento e consumo promovida pelas políticas públicas para o caso do Brasil. 


\subsection{JUSTIFICATIVA}

O interesse pelo tema surgiu a partir da leitura do livro "O Desafio Brasileiro na Era dos Gigantes" de Samuel Pinheiro Guimarães, quando o desenvolvimento se tornou interesse de estudo em meus trabalhos acadêmicos.

A participação em um programa de capacitação acadêmica na Missão do Brasil junto às Nações Unidas trouxe a inquietação em torno de um tema que merece maior atenção e que está em pauta na agenda de desenvolvimento dos mais diversos países ao redor do globo.

O desenvolvimento sustentável, com sua ideologia voltada para atender as necessidades da geração atual sem comprometer as gerações futuras, passa a ser meu interesse de pesquisa ao perceber que programas e políticas públicas podem ser elaborados visando o bem-estar social sem prejudicar o meio ambiente. O conceito passou a ser compreendido dentro das negociações da nova agenda de desenvolvimento da ONU como um processo que envolve três dimensões, sendo elas: econômica, social e ambiental.

Dentro deste conceito, os padrões de produção e consumo sustentáveis se tornam essenciais para a evolução de políticas públicas no que tange ao desenvolvimento sustentável.

Durante muito tempo a questão da produção predominava nas discussões referentes a este tema. Nos últimos anos, porém, o consumo tem surgido como um dos principais fatores que influenciam de fato o desenvolvimento sustentável, e com isso, também influenciam diretamente nas políticas públicas. A análise de dados do governo brasileiro foi escolhida em função do papel que o Brasil possui como um dos principais articuladores de uma nova estratégia de desenvolvimento e de sua capacidade em influenciar as decisões de uma agenda internacional.

Acredita-se, portanto, que este estudo pode contribuir com os estudos da área, por abordar as principais relações entre o crescimento econômico, as políticas públicas e o meio ambiente, bem como discutir a importância destes aspectos para o desenvolvimento sustentável. Insere-se principalmente na temática de gestão de políticas públicas, por buscar a discussão sobre a coerência entre diferentes políticas e documentos norteadores do desenvolvimento do país. 


\section{CONSUMO E MEIO AMBIENTE}

O fenômeno da Revolução Industrial marcou uma nova era do desenvolvimento capitalista no mundo, dando início ao ciclo do motor à combustão. Para Morais e Costa (2010), constituiu-se um novo padrão de produção e de consumo com base em modernos sistemas de produção e comercialização, onde o elemento símbolo desta transformação foi o automóvel, bem como a utilização de uma série de produtos propiciada pela eletricidade e pelos avanços na indústria de bens de consumo duráveis, com elevadas escalas de produção e de consumo.

Esse padrão de produção e consumo constituiu-se definitivamente no Brasil em meados dos anos 1950 com a intensificação do processo de industrialização do governo Juscelino Kubitschek. Neste período, a industrialização acelerada, juntamente com a rápida urbanização, multiplicou as oportunidades de investimento e de geração de emprego e renda. Porém, esse processo veio acompanhado de um aumento da desigualdade e concentração de renda, gerando um aumento da pobreza e da miséria urbana (MORAIS, COSTA, 2010).

As características deste modelo concentrador de renda colocam como questão central um novo projeto de desenvolvimento capaz de aliar o crescimento econômico, a inclusão social e a sustentabilidade ambiental. Segundo Morais e Costa (2010), tornase obrigatório refletir e discutir sobre os padrões atuais de produção e consumo, uma vez que foram moldados pela lógica de desenvolvimento gestada com a Revolução Industrial e pela ideia de crescer continuamente para atender a necessidade de acumulação do capital. Os autores acreditam que essa lógica nos distanciou das necessidades básicas, bem como parece ter influido negativamente na forma pela qual nos relacionamos em sociedade e com o meio ambiente.

Segundo Bauman (2007), os atos de consumo têm fins claros, durando apenas até se concretizar e nem um minuto a mais, porém não se pode dizer o mesmo sobre as interações humanas, já que cada encontro deixa para trás um sedimento de vínculo humano e esse sedimento se torna mais espesso com o tempo a medida em que se enriquece com as memórias do convívio.

A alternativa necessária para a permanência humana no planeta deve vir com uma modificação no paradigma de desenvolvimento até então praticado. Para isso, o desenvolvimento sustentável surge como a opção mais favorável a emergir como fator de referência para nortear a dinâmica de crescimento e de desenvolvimento que a estrutura econômica venha a utilizar, na medida em que preceitos que envolvem a articulação e o envolvimento por parte da coletividade são utilizados (SILVA, 2011). 
O conceito de desenvolvimento sustentável, utilizado pela primeira vez em 1987 no Relatório Brundtland, começou a apontar para o uso racional dos recursos naturais na satisfação das necessidades da atual geração, sem comprometimento à capacidade das gerações futuras em prover suas próprias necessidades.

A definição do Relatório Brundtland reconhece a dependência dos seres humanos com relação ao meio ambiente para atender suas necessidades e seu próprio bem-estar em um sentido muito mais amplo do que simplesmente a exploração de recursos (HOPWOOD et al, 2005).

Em contrapartida, Herculano (1992) argumenta que para o Relatório Brundtland, a pobreza e a deterioração ambiental formam um círculo vicioso no qual cada termo é efeito e causa do outro. Para a autora:

\begin{abstract}
Além da injustiça cega que é não mencionar com a mesma insistência a degradação ambiental trazida pelo crescimento exponencial e o consumismo do Primeiro Mundo, o Relatório não aventa a hipótese de que pobreza e deterioração ambiental sejam ambas efeitos indesejáveis de um modelo de crescimento que prioriza o incremento de capital e não atender às necessidades humanas. Pobreza e degradação ambiental não são percebidas pelo Relatório enquanto características inerentes à lógica perversa de um modo de produção concentrador, mas como percalços inesperados, passíveis de serem contornados e controlados através de políticas de ajustes e correções (HERCULANO, 1992, p. 15).
\end{abstract}

Foi somente durante os preparativos para a Rio92 que as negociações preliminares começaram a envolver debates acerca do estilo de vida, práticas de consumo e problemas ambientais. Os documentos produzidos durante a conferência apontaram para a responsabilidade dos estilos de vida e consumo. O princípio 8 da Declaração proclama que "para alcançar o desenvolvimento sustentável e uma qualidade de vida mais elevada para todos, os Estados devem reduzir e eliminar os padrões insustentáveis de produção e consumo, e promover políticas demográficas adequadas" (NAÇÕES UNIDAS, 1992).

De acordo com Amaro (2012), o termo "insustentáveis" é utilizado porque não é possível extrair mais recursos naturais do que a natureza é capaz de repor nem extrair indefinidamente recursos finitos, não renováveis, bem como descartar mais resíduos do que a natureza é capaz de assimilar.

O crescimento da população mundial e da produção, associado aos padrões não sustentáveis de consumo, aplica uma pressão cada vez mais intensa sobre as condições que nosso planeta tem de sustentar a vida. Segundo a Agenda 21, adotada durante a Conferência do Rio, as principais causas da deterioração ininterrupta do meio ambiente mundial são os padrões insustentáveis de produção e consumo, sendo motivo 
de séria preocupação, pois provocam o agravamento da pobreza e dos desiquilíbrios ambientais.

O foco do desenvolvimento sustentável, neste sentido, começa a considerar a mudança de paradigma do princípio estruturante e organizador da sociedade moderna, da produção para o consumo. E, para isso, os governos desempenham um papel vital na modificação da arquitetura institucional da sociedade de consumo através de suas políticas públicas (OLIVEIRA et al, 2011).

Contudo, para Portilho (2005), analisar a sociedade a partir de uma abordagem orientada pelo consumo traz inúmeras implicações, não apenas para as ciências sociais e para as políticas ambientais, mas também em termos de novas possibilidades de ação política.

Os desafios do desenvolvimento sustentável implicam em uma necessidade de formar capacidades para orientar um desenvolvimento fundado em bases tecnológicas, de equidade social, diversidade cultural e democracia participativa (LEFF, 1999).

Deve-se levar em conta que o desenvolvimento sustentável não é homogêneo, ele expressa estratégias conflitantes que respondem a visões e interesses diferenciados. Para Leff (1999), a perspectiva economicista privilegia o livre mercado como mecanismo para internalizar as externalidades ambientais e para valorizar a natureza e com isso, recodificar a ordem da vida e da cultura em termos de um capital natural e humano. Seguindo uma linha semelhante, Sachs (2009) afirma que o desenvolvimento sustentável é incompatível com o jogo sem restrições das forças de mercado. Para este autor, o crescimento econômico deveria ser socialmente receptivo e implementado por métodos favoráveis ao meio ambiente, em vez de favorecer a incorporação predatória do capital da natureza ao Produto Interno bruto (PIB).

Eddine et all (2008) acreditam que o desenvolvimento sustentável, construído com base nos limites da economia de mercado, implica em uma falsa interpretação da sustentabilidade, pois não se pode admitir que a substituição da natureza pelo capital seja algo sustentável, não havendo como separar a produção e o consumo da conservação da natureza. Para os autores, a verdadeira sustentabilidade vai exigir que o mercado e o processo de produção e de consumo sejam reformulados.

Para que haja o alcance do desenvolvimento sustentável, Silva (2011) pontua a necessidade de realização de práticas que envolvem um papel mais ativo do governo, uma responsabilidade socioambiental das empresas, bem como uma maior consciência individual ao modificar suas atitudes enquanto integrante da sociedade. Logo, observase a complexidade das ações e políticas necessárias para 0 alcance do desenvolvimento sustentável. 
Dinato e Nascimento (2003) citam Romeiro et all (1996) para assinalar que está consolidada a consciência de que simplesmente não é possível, do ponto de vista ecológico, a generalização, em escala mundial, dos padrões tecnológicos de produção e de consumo prevalecentes nas atuais economias industriais. Segundo Sodré (1996), o ato de consumir se opõe a ideia de preservar, sendo preciso repensar esta relação. Por outro lado, a ideia ingênua de preservar corre o risco de esquecer a necessidade do homem de consumir. Segundo o autor:

Repensar esta sociedade de uma forma realística é absolutamente imprescindível. Não se trata de opor preservação ao consumo, mas de buscar uma saída que pode ser denominada consumo sustentável (SODRÉ, 1996, p. 153).

De acordo com Silva (2012), consumo sustentável pode ser entendido como:

o padrão de consumo resultante da inter-relação de atores sociais, numa perspectiva de interação política, direcionado ao alcance do desenvolvimento sustentável, pressupondo a existência de uma consciência individual (ao considerar o indivíduo como cidadão), de um alinhamento organizacional direcionado aos aspectos socioambientais, por uma atuação governamental ativa, bem como de outros atores pertencentes ao contexto social, por meio da coordenação das práticas e relações existentes na dinâmica do consumo sustentável (SILVA, 2012, p. 255).

Para o Programa das Nações Unidas para o Meio Ambiente, segundo o Processo Marrakesh, de 2003, consumo sustentável é considerado como:

o uso de bens e serviços que atendam às necessidades básicas, proporcionando uma melhor qualidade de vida, enquanto minimizam o uso dos recursos naturais e materiais tóxicos, a geração de resíduos e a emissão de poluentes durante todo ciclo de vida do produto ou do serviço, de modo que não se coloque em risco as necessidades das futuras gerações (PNUMA, 2003)

Por sua vez, o governo brasileiro, em documento oficial ${ }^{1}$, considera o consumo sustentável como:

aquele que demanda tais produtos e serviços, considerando como estes podem atender as necessidades humanas (alimento, abrigo, vestuário, lazer, mobilidade), reduzindo ao máximo os impactos ambientais em todo o ciclo de vida e mantendo-se dentro da capacidade de carga dos ecossistema (BRASIL, 2011).

Para Cortez e Ortigoza (2007), o tratamento que se dá ao conceito de consumo sustentável deveria ser o de prevenção, garantindo o consumo, mas que seus padrões

\footnotetext{
${ }^{1}$ Conceito expresso no Plano de Ação para Produção e Consumo Sustentável.
} 
se modifiquem a fim de minimizar os impactos ambientais do descarte e o uso exagerado dos recursos naturais.

Pode-se dizer que o consumo sustentável é forma como a sociedade deveria comportar-se mediante a disponibilidade de recursos existentes com vistas a um equilíbrio maior para o futuro. Neste sentido, o governo desempenha um papel fundamental na construção de políticas que visem estimular uma melhor condição de vida para a população sem maiores prejuízos ao meio ambiente. Porém, não basta apenas uma ação por parte do governo, as empresas e os próprios indivíduos devem colocar-se como principais atores na busca por um desenvolvimento sustentável.

Cortez e Ortigoza (2007) chamam atenção para a dimensão individual do consumo sustentável. Para as autoras:

será preciso, igualmente, uma mudança nas atitudes sociais e culturais, de modo que a liberdade pessoal de desfrutar de benefícios materiais aqui e agora seja contrabalançada por um sentimento de responsabilidade compartilhado, a fim de promover o bem-estar de toda a humanidade, incluindo o das gerações futuras (CORTEZ; ORTIGOZA, 2007, p.12).

De acordo com Ortigoza (2003), a essência do consumo sustentável está em se criar uma consciência ecologicamente seletiva nos consumidores, desenvolvendo dentro do cotidiano novos hábitos de consumo mais responsáveis e com menor volume de desperdício. A autora aponta para os 3R's para destacar que é preciso uma educação para a redução, pois nem tudo que consumimos é realmente uma necessidade; para a reutilização, pois muitos dos produtos que consumimos podem servir para novos usos; e por fim, para a reciclagem, pois é possível introduzir novamente ao sistema produtivo os produtos já utilizados a fim de que se transformem em novos produtos.

A autora ainda aponta o consumo sustentável como uma das possibilidades de minimização dos impactos gerados pelos resíduos sólidos no espaço urbano, pois não basta trabalharmos apenas com os resultados, ou seja, o lixo gerado, mas é preciso a criação de mecanismos de diminuição desta geração, e para isso, mudanças comportamentais nas relações de consumo são necessárias.

Segundo Pujadas et al (2009), é possível compreender o consumo sustentável a partir de três enfoques: ecológico, econômico e social. O enfoque ecológico é caracterizado pela necessidade ecológica de mudança dos atuais padrões de consumo; o enfoque econômico aborda o consumo como o principal motor de crescimento do mundo e problematiza a forma de encontrar um desenvolvimento econômico que permita cumprir as necessidades humanas ao mesmo tempo em que preserva o entorno 
natural e assegura a distribuição equitativa dos recursos mundiais; o enfoque social, por sua vez, trata da mudança dos hábitos de consumo e dos meios de relação social que são motivados por uma série de critérios e fatores que podem ser de interesse pessoal ou por motivos sociais.

A ideia de um consumo sustentável surge como um fator basilar para o desenvolvimento sustentável, na medida em que dentre as relações de complexidade que o mesmo assume, visualizam-se mudanças significativas entre os diferentes atores sociais envolvidos e para isso, o governo possui dentre outras responsabilidades à de estimular novas práticas sociais, por meio de incentivos, regulamentação ou fomento a uma atuação diferenciada da sociedade (SILVA, 2012).

Segundo Maduro-Abreu (2010), o surgimento do termo de consumo sustentável traz uma perspectiva mais ampla para se pensar o consumo. Segundo o autor, abandona-se a visão exclusiva da relação entre o consumo e a utilização de recursos naturais nos processos produtivos e seus impactos no meio ambiente e começa a se obter uma visão também sobre os impactos sociais.

Silva (2012) cita Silva \& Gómez (2011) para apontar como imprescindível o papel do governo em estimular ou incentivar outros atores para práticas sustentáveis, ao assumir seu papel por meio de políticas públicas, programas educacionais, fomento e financiamento de projetos, etc. Em uma perspectiva do consumo sustentável, os governos podem promover e facilitar o desenvolvimento de tecnologias limpas, bem como transferi-las e adotá-las, assumindo ainda o papel de apoiar pesquisas para o fornecimento de informações de produção e consumo, tanto para a indústria como para os próprios consumidores. Segundo Eddine et al (2008), as políticas de consumo sustentável devem incluir instrumentos para encorajar mudanças, como o design dos produtos e a informação nos rótulos.

Mas para que as práticas de consumo sejam reestruturadas, uma abordagem mais ampla se faz necessária, envolvendo mudanças no debate público sobre a relação entre consumo e qualidade de vida, encorajando a integração das preocupações ambientais nas práticas de consumo, enfrentamento das ações regulatórias na esfera da mídia e dos mecanismos de marketing através da ampla participação dos diferentes setores envolvidos.

O tratamento dado ao consumo sustentável tem um sentido preventivo, sendo necessário que o consumo seja garantido, mas que seus padrões se modifiquem a fim de minimizar os impactos ambientais do descarte e do uso exagerado dos recursos naturais (EDDINE et al, 2008).

Uma nova atuação de diferentes atores apresenta-se como essencial para o estabelecimento de um paradigma de desenvolvimento sustentável, tendo em vista que 
a partir de práticas que envolvem um papel mais ativo do governo, uma responsabilidade socioambiental das empresas, uma maior consciência individual, pode emergir uma nova atuação coletiva que atende os requisitos desse tipo de desenvolvimento pela prática do consumo sustentável, por exemplo (SILVA, 2012).

A busca de uma compreensão e alternativas viáveis aos crescentes desafios emanados de problemas essenciais da humanidade, como a relação entre as sociedades humanas e a natureza, elevaram o debate sobre o consumo sustentável a um novo patamar. Numa economia baseada na supremacia dos direitos do consumidor e na garantia de suas liberdades de escolha, confrontar o consumo sob a ótica da escassez, da desigualdade e da necessidade de limites parece temerário, ao mesmo tempo em que parece inevitável inserir o tema em debates acadêmicos para contribuir com os questionamentos, nas reflexões e até mesmo na proposição de alternativas para os grandes dilemas socioambientais frente a padrões de produção e consumo e de desenvolvimento que apresentam indesejáveis efeitos colaterais na forma de exclusão social e degradação ambiental (DINATO; NASCIMENTO, 2003).

\subsection{A PRODUÇÃO E CONSUMO DE BENS E SERVIÇOS COMO FONTE DINÂMICA ECONÔMICA E SOCIAL}

O consumo é um conceito complexo que abrange múltiplas atividades e uma gama enorme de bens e serviços. Segundo Warde (1997), muitos economistas neoclássicos e alguns analistas focam em compras pessoais no mercado. Porém, sob qualquer definição genérica dos propósitos e funções do consumo, existem várias outras fontes de produtos que podem ser consumidos. O papel do Estado na prestação dos serviços chamados de consumo coletivo, por exemplo, foi examinado por sociólogos urbanos.

A questão do consumo é complexa, pois ela é influenciada não somente pelas mercadorias vendidas e a quais preços, mas também são influenciadas pelos arranjos domésticos, pela política governamental, pela organização comunitária e por conflitos industriais. A identificação dos diferentes modos de prestação de serviços que contribuem para o consumo levanta algumas questões em torno de como eles são articulados e como eles se desenvolvem com o passar do tempo. Para Warde (1997), não é mais possível que a análise do consumo esteja baseada na ideia de "quem compra o que?", mas sim na ideia de "quem obtém tais serviços (ou bens), sob quais condições são entregues e quais são as devidas utilidades?".

Cavalcanti (2002) cita Viola (1996) para enfatizar que em uma sociedade sustentável, o progresso deve ser apreendido pela qualidade de vida e não pelo puro 
consumo material. Renda nacional e PIB referem-se a progresso material, mas é à base de seus valores, obtidos por meio do sistema de contas nacionais, que políticas de desenvolvimento são geralmente concebidas e avaliadas.

O crescimento da população mundial e da produção, associado aos padrões não sustentáveis de consumo, gera uma pressão cada vez mais intensa sobre as condições que nosso planeta tem de sustentar a vida. Com a população prevista para alcançar nove bilhões de pessoas até meados do século, a economia vem sufocando a capacidade natural de geração de serviços ambientais necessários para o bem-estar humano. Enriquez (2010) destaca que o custo de oportunidade no uso de recursos naturais passou a ser muito alto devido ao comprometimento da geração dos serviços ecossistêmicos. Atividades que mantêm ou elevam apenas o bem-estar econômico ocorrem às expensas da qualidade ecológica ao ponto de que uma atividade comercial, como a mineração, pode beneficiar a economia nacional à custa de danos aos valores culturais de comunidades locais.

Eddine et al (2008) afirmam que a situação degradante pela qual passa o meio ambiente está intimamente relacionada ao modelo de desenvolvimento capitalista adotado. Sendo o estímulo ao consumo a base do modelo de desenvolvimento, a natureza começa a sofrer sinais negativos devido ao inesgotável uso de matéria-prima e energia e do abrigo indevido de dejetos produzidos por suas cidades e indústrias. Segundo Bonaiuti (2012), o sistema capitalista, cujas instituições, apesar de estarem sujeitas a transformações, e que tem base no crescimento econômico contínuo, está demonstrando ser incompatível com a manutenção dos equilíbrios ecológicos e sociais.

O capitalismo está construído sobre o consumo, dependendo estruturalmente do crescimento econômico contínuo. O aumento do consumo pessoal é um elemento chave do dinamismo capitalista e o comportamento consumista está inserido em uma economia que depende do consumo abundante para a sobrevivência. Matias (2014) cita Kyla Tienhaara para afirmar que a facilidade em obter crédito encoraja e permite que os indivíduos vivam além dos seus próprios recursos e também além dos recursos do meio ambiente global.

Para Costa et al (2014), o consumismo é a engrenagem que sustenta o capitalismo e alimenta o cerne de empresas em oferecer produtos que determinam tendências capazes de gerar mais renda. As políticas adotadas por bancos e entidades que prestam serviços de crédito, inúmeras vezes, relevam possibilidades financeiras necessárias para a atividade de consumo, nutrindo o sistema capitalista.

A busca pela manutenção do crescimento econômico do país traz consigo a implantação de técnicas de consumo e de produção que acabam criando um grande impacto sobre o meio ambiente. Camargo (2003), afirma que o modelo econômico de 
desenvolvimento modifica e aperfeiçoa a relação do ser humano com o meio ambiente em diversos aspectos, mas ao mesmo tempo, também provoca transformações dramáticas no ambiente natural. Os recursos renováveis não têm poder de se autoreproduzirem na velocidade exigida pela lógica do crescimento acelerado e os ecossistemas não têm capacidade de absorver indefinidamente os resíduos gerados pela sociedade industrial.

Cada vez mais os produtos ganham menos tempo de vida útil, o conserto cada vez mais é difícil de ser conseguido e isto leva a um impulsionamento do consumo e da produção pela praticidade em se comprar um produto novo ao invés de arrumar o antigo. Além disso, o mercado cada vez mais lança novos produtos e atrai o consumidor a trocar seu produto antigo por novos, mesmo que aqueles ainda estejam em boas condições (COSTA; IGNÁCIO, 2011).

A razão de compra deixou de ser a necessidade pelo produto e passou a ser a vaidade, o preço acessível, o marketing do produto, uma pequena inovação e até mesmo os grupos sociais com menores rendas passam a acumular bens sem que eles sejam utilizados de forma efetiva, contribuindo para o desperdício e o uso abusivo dos recursos naturais. $O$ incentivo ao consumo dos mais variados tipos de bens, inclusive daqueles que trazem as mais avançadas inovações tecnológicas, é uma das grandes dificuldades do modelo econômico propagado pela sociedade capitalista (BRUM; HILLIG, 2010).

Para Warde (1997), os padrões de consumo podem ser explicados de acordo com os julgamentos sociais na formação das identidades de classe social. O autor cita Bordieu para afirmar que o comportamento do consumo é um meio pelo qual as classes sociais exibem seu capital cultural e seu lugar em um sistema hierárquico de distinção social. As práticas de consumo, nesse sentido, são geradas pelo habitus, um conjunto de disposições que sustentam e geram julgamentos sociais e culturais.

O principal objetivo de um consumidor passa a ser ganhar ou manter o controle das fontes de informação, assegurando suas interpretações racionais, pois, segundo Castaneda (2010), cada pessoa constitui uma fonte e um objeto de julgamentos, encontrando-se inserida em um esquema de classificação que, em parte, é estabelecido por meio de suas próprias discriminações.

O consumo deixou de ser uma ocupação dos seres humanos e passou a ser um atributo da sociedade. Para atender as necessidades, desejos e impulsos, a economia consumista baseia-se no excesso e no desperdício. O consumo, como atributo da sociedade contemporânea, torna o indivíduo alienado da atividade primitiva do ser humano de consumir para sobreviver (BAUMAN, 2008). 
O fato é que, conforme a escala da economia aumenta, mais resíduos são produzidos, mais sistemas naturais são danificados, mais direitos das gerações futuras são prejudicados e mais grupos da geração presente deixam de ter acesso a recursos e serviços ambientais (ALIER, 2002).

O consumo total da economia humana tem excedido a capacidade de reprodução natural e assimilação de rejeitos da ecosfera, enquanto fazemos uso desigual e injusto das riquezas produzidas. Porém é necessário levar em consideração o fato de que o consumo possui muitas dimensões, para Portilho (2010), o consumo

[...] não é somente a prática de uma série de ações como escolha, compra, uso e, finalmente, descarte. Contra essa imagem, muitos autores apontam para o fato de que o consumo é um fenômeno mais significante e mais central para o entendimento da sociedade contemporânea do que os acadêmicos têm tradicionalmente considerado. Da mesma forma, o consumidor não deve ser visto exclusivamente como vítima passiva e manipulada pelas forças de mercado e pelas oscilações da moda (PORTILHO, 2010, p.28).

Baurdrillard (1991) caracteriza a sociedade como uma sociedade de consumo e a define como uma sociedade de produção de bens e de relações. Ela é caracterizada pela abundância de bens e serviços, onde nada do que se oferece para ser consumido se apresenta como um produto puro e simples, mas como um serviço pessoal, como uma gratificação. A sociedade de consumo é um modo novo e específico de socialização que está relacionado com o surgimento de novas forças produtivas e com a reestruturação monopolista de um sistema econômico de alta produtividade.

De acordo com Portilho (2010), a sociedade de consumo pode ser considerada de três maneiras diferentes:

Em primeiro lugar, a Sociedade de Consumo é vista como uma sociedade capitalista, dependente, para sua expansão, do desenvolvimento do capitalismo industrial. Esta perspectiva é facilmente associada ao marxismo e suas variações teóricas orientadas pela divisão de classe, que percebe a sociedade de consumo como sendo dirigida pelo lucro. [... Em segundo lugar, a Sociedade de Consumo é vista como uma sociedade racional e utilitária, feita, simplesmente, por consumidores praticando o ato de consumir. Esta é a visão elaborada e defendida pela teoria econômica clássica e pelas abordagens relacionadas aos estudos de marketing e propaganda. [...] Uma terceira e mais recente perspectiva vê a Sociedade de Consumo como uma sociedade simbólica e de sinais e significados, enfatizando a construção e fortalecimento das identidades individuais e sociais através da aquisição e uso de bens. Neste sentido, é parte do chamado hipercapitalismo ou capitalismo pós-industrial e não inclui somente o consumo de bens materiais, mas também e principalmente, dos chamados bens intangíveis. Trata-se de uma perspectiva associada aos Estudos Culturais e as teorias da pós modernidade (PORTILHO, 2010, p. 104). 
O consumo aparece ligado a questão do trabalho/produção, sendo assim, a realização do trabalho e da produção, a realização do essencial do ser humano. Sob a ótica do capitalismo, esta relação entre trabalho e consumo se rompe, pois os trabalhadores não mais se engajam em atividades para produzir produtos que satisfaçam suas próprias necessidades, mas vendem sua força de trabalho por salário tornando o consumo como o consumo de produtos criados por outros, os quais o propósito inicial não teria sido a satisfação de uma necessidade, mas a obtenção do lucro (PORTILHO, 2010).

A sociedade de consumo, segundo a abordagem marxista, indica uma manipulação do consumo pelo capitalismo industrial. Nesta perspectiva, a sociedade de consumo seria aquela dominada pelos imperativos do lucro que criam necessidades falsas através da manipulação dos consumidores sem gerar felicidade, satisfação ou harmonia. O marketing e a propaganda, neste sentido, se enquadram mais em comprar os consumidores do que a própria venda do produto (BARBOSA, 2004).

Para Eddine et al (2008), quanto mais conforto as pessoas têm, mais elas esperam ter, sendo assim, uma sociedade voltada à produção e aquisição crescentes de bens de consumo cada vez mais diversificados. E neste sentido, a sobrevivência dessa sociedade, depende da criação de necessidades de aquisição de novos produtos e quando essa necessidade não existe, há a possibilidade de criá-la, embuti-la na consciência do consumidor. Para os autores, não é a tecnologia que atende as nossas necessidades, como os meios de comunicação nos fazem crer, mas as necessidades é que são criadas para atender à crescente população e à elaboração cada vez mais diversificada dos bens de consumo.

Segundo Pereira e Calgaro (2012), as relações de consumo, enquanto espécie das relações sociais, desenvolvem-se em um plano de dominação e alienação política, econômica, social e até mesmo cultural. A sociedade moderna se forma em condições que programam um novo estilo de vida, onde o ser humano perde sua essência para se transformar em um ser consumidor. A busca por ascensão e por poder conduz o ser humano moderno à estratificação social e a uma vinculação com o consumo em que os bens materiais the proporcionam não somente conforto e possibilidade de sobrevivência, mas principalmente o status social e o poder frente aos demais membros da sociedade (PEREIRA; CALGARO, 2012).

Para Pereira e Calgaro (2012), a sociedade moderna se torna cruel no instante em que vincula a felicidade ao consumo de bens e serviços afastando o ser humano de si mesmo, de suas crenças, de pessoas e vinculando-o ao ato de consumir. 
Segundo Bauman (2007), a luta pela singularidade se tornou o principal motor da produção e do consumo de massa. Neste sentido, para colocar o anseio por singularidade a serviço do mercado de consumo de massa (e vice-versa), o autor aponta que uma economia de consumo também deve ser uma economia de objetos de envelhecimento rápido, obsolescência quase instantânea e veloz rotatividade, gerando assim excesso e desperdício.

Para Bauman (2007), a vida de consumo é uma vida líquida. Nela o lixo é o principal e mais abundante produto da sociedade líquido-moderna de consumo. Entre as indústrias da sociedade de consumo, a de produção de lixo é a mais sólida e imune a crises, fazendo com que a remoção do lixo seja um dos dois principais desafios que a vida líquida precisa resolver. O segundo desafio é a ameaça de ser jogado fora. Em um mundo repleto de consumidores e produtos, a vida flutua entre os prazeres do consumo e os horrores da pilha de lixo.

De acordo com o autor, a sociedade de consumo não é nada além de uma sociedade do excesso e da fartura, portanto da redundância e do lixo farto, pois quanto mais fluido o ambiente de suas vidas, mais os atores precisam de objetos potenciais de consumo para proteger suas apostas e garantir suas ações em relação aos caprichos do destino.

O consumo, sendo uma prática constante do ser humano, quando se torna extravagante, passa a ser conhecido como consumismo. Esse excesso de consumo, segundo Silva (2012), indica uma despreocupação dos indivíduos quanto aos aspectos da coletividade, à medida que a consequência individualista indica o pensamento alieando quanto à abundância de recursos do meio ambiente. $E$ tal fato demonstra a necessidade de mudança na maneira com a qual se visualiza o modelo de desenvolvimento atual e consequentemente, das práticas de consumo.

Scantimburgo (2011) acredita que em nossa sociedade, o limite da sustentabilidade ambiental passa a ser a ordem capitalista vigente, pois os diferentes interesses que giram em torno da questão ambiental têm seus limites, suas aspirações, impostos pela economia de mercado e pelo modo de produção capitalista. Para o autor, o capitalismo, com um discurso de preservação ambiental e bem-estar das pessoas, absorve a crise ambiental como forma de se obter novas frentes de acumulação de capital ao valorizar economicamente o meio ambiente. Neste sentido, o autor pontua que a visão que parte de órgãos como o Banco Mundial, a ONU e o FMI, não teriam outra saída a não ser seguir um desenvolvimento sustentável adaptado às leis do livre mercado e que não altere as relações sociais de modo de produção capitalista.

Costa e Ignacio (2011) afirmam que o espírito capitalista domina o mundo atual e colocam o consumo como o ápice do ideal da sociedade, onde a arte de consumir é o 
padrão, e quanto mais se consome, maior se torna o desenvolvimento e a estabilidade econômica de cada Estado. Neste sentido, o consumo não pode ser entendido somente como um ato individual, mas como uma questão ligada a forma como as nações optam por se desenvolver.

\subsection{CONSUMO, MEIO AMBIENTE E DESENVOLVIMENTO}

Os esforços para criar um diálogo sobre como o consumo possa estar vinculado com o meio ambiente aparecem um pouco confusos devido as dificuldades enfrentadas com relação aos conceitos fundamentais e na criação de limites em torno da discussão. Grande parte dessa dificuldade, segundo Cohen e Murphy (2001), resulta do fato de que o consumo pode ser considerado, de um lado, uma atividade material que envolve unidades físicas de óleo, madeira etc., e por outro lado, a aquisição de bens está inegavelmente atada às práticas culturais que visam atingir diversos objetivos sociais, incluindo a produção ou reprodução de valores, uma sociedade coesa e a uma identidade individual.

Para Castaneda (2010), o termo consumo muitas vezes é utilizado fazendo referência a compras e aquisições. Para o autor, as práticas de compra são integrativas pois envolvem nexos de fazeres e discursos que estão relacionados tanto com o que as pessoas gostam ou odeiam comprar quanto com a disposição de algumas pessoas em evitar comprar. Ainda assim, o autor argumenta que o consumo constitui um fenômeno inescapável e momentâneo, ocorrendo frequentemente e sem muita importância por grande parte das pessoas.

A questão do consumo, como objeto principal de estudos do foco da sustentabilidade, constata que a relação da sociedade com a natureza não considera a finitude dos sistemas naturais. De acordo com Oliveira et al (2011), a maioria dos estudos realizados sobre o impacto do consumo no meio ambiente faz uma fragmentação do tema. Alguns analisam a visão de como as empresas agem em relação à natureza e em outros se discute a sensibilidade dos consumidores sobre a questão ambiental. As considerações a respeito da importância das políticas públicas para o desenvolvimento sustentável ainda são pequenas comparadas às anteriores.

Oliveira et al (2011) citam Jackson \& Michaelis (2003) para demonstrar que estamos presos a atual evolução do consumo por uma combinação de escolhas passadas, tecnologias, incentivos econômicos, instituições, nossa própria psicologia e os sistemas culturais e sociais em que vivemos. Portanto, para alcançar a um possível 
consumo sustentável seria necessário modificar os padrões de consumo da sociedade capitalista moderna.

A performance bem-sucedida das economias capitalistas modernas pode ser caracterizada pela abundância dos bens de consumo continuamente produzidos pelo sistema industrial. Para Portilho (2010), esta abundância passou a receber uma conotação negativa ao receber críticas que consideram o consumismo um dos principais problemas das sociedades industriais modernas.

Altvater (1995) aponta que esse modelo de industrialização capitalista não é universalizável e que não parece possível espalhar pelo mundo todo um modo de vida e de trabalho que se baseia em um elevado nível energético e material. Por outro lado, Furtado (1974) afirma que o desenvolvimento econômico, como vem sendo praticado pelos países que lideraram a revolução industrial, pode ser universalizado se os padrões de consumo da minoria da população forem acessíveis às grandes massas de população em rápida expansão.

A exploração excessiva dos recursos naturais e a iniquidade inter e intrageracional na distribuição dos benefícios oriundos dessa exploração, segundo Portilho (2010), conduziram a reflexão sobre a insustentabilidade ambiental e social dos atuais padrões de consumo e seus pressupostos ético-normativos.

Os padrões de consumo não são somente insustentáveis, eles também são desiguais. Os países mais ricos, que correspondem a $1 / 5$ da população, respondem por $45 \%$ do consumo de carne, $58 \%$ do consumo de energia, $84 \%$ do papel e $87 \%$ do uso e propriedade dos veículos motorizados, enquanto o 1/5 mais pobre da população mundial, sofre de carência de alimentação, abrigo, habitação, água, saneamento básico e acesso à eletricidade (DINATO; NASCIMENTO, 2003).

Segundo Portilho (2010), 20\% da população mundial, habitantes principalmente dos países afluentes do hemisfério norte, consome $80 \%$ dos recursos naturais e energia do planeta e produz mais de $80 \%$ da poluição e da degradação dos ecossistemas, enquanto os $80 \%$ da população mundial, habitantes principalmente dos países do hemisfério sul, ficam com apenas $20 \%$ dos recursos naturais.

O meio ambiente deixou de ser relacionado simplesmente a uma questão de como usamos os recursos, mas agora passa a incluir também uma preocupação com o quanto usamos, tornando-se assim, uma questão de acesso, distribuição e justiça (PORTILHO, 2010).

Esse modelo de desenvolvimento excessivamente consumista é altamente impactante tanto do ponto de vista social como ambiental. É por isso que a grande questão que se coloca hoje em dia é a busca de um novo modelo de desenvolvimento e de consumo que não cause tantos impactos no meio ambiente, que seja 
ecologicamente sustentável e que promova uma melhor distribuição da riqueza no mundo.

Para Viegas (2010), o incentivo ao consumo leva ao distanciamento entre as camadas mais abastadas, com maior poder de consumir, e as camadas com menor renda, que enfrentam adversidades para se apropriar do mínimo imprescindível à sobrevivência. Em um contexto marcado pela industrialização, concentração populacional e estímulo ao consumo, as características basais da sociedade moderna, as dificuldades ambientais e sociais se acirram e o acesso ao consumo se torna desigual ou até mesmo inexistente.

O consumo de itens necessários à sobrevivência, como aqueles encontrados em supermercados, pode afetar positiva ou negativamente a vida das pessoas, pois proporcionam o alargamento das suas competências e dignidade de vida. Segundo Viegas (2010), as populações sem acesso a alimentação ou água potável, por exemplo, têm baixas possibilidades de usufruir de uma vida digna, bem como a oportunidade de desenvolver suas capacidades.

Partindo desse ponto, Sachs (2009) afirma que o desenvolvimento sustentável é um desafio planetário que necessita de estratégias complementares entre os países do Norte e do Sul, dado que os padrões de consumo do Norte são insustentáveis e implicam em uma mudança no estilo de vida, lado a lado com a revitalização dos sistemas tecnológicos, enquanto no Sul, a reprodução dos padrões de consumo do Norte em benefício de uma pequena minoria resulta em uma apartação social.

Para Furtado (1974), a evolução do sistema capitalista deu-se em função das seguintes características: homogeneização e integração do centro; distanciamento crescente entre o centro e a periferia; ampliação considerável do fosso que separa uma minoria privilegiada e as grandes massas da população. Com isso, a intensidade de crescimento do centro condicionava a orientação da industrialização na periferia, pois as minorias buscavam reproduzir o estilo de vida do centro.

Para o mesmo autor, o dinamismo econômico no centro do sistema decorre do fluxo de novos produtos e da elevação dos salários reais que permitem que haja um aumento do consumo de massa, enquanto o capitalismo periférico engendra 0 mimetismo cultural e requer uma permanente concentração de renda a fim de que as minorias possam reproduzir as formas de consumo dos países cêntricos.

Países industriais são dependentes das importações do Sul como parte do seu requisito de crescimento no que tange a matéria prima e bens de consumo, pois fronteiras de petróleo e gás, por exemplo, estão avançando em novos territórios e criando grandes impactos, os quais já foram desproporcionalmente sentidos por grupos 
sociais que tendem resistir. Alier (2002) aponta, portanto, que o crescimento econômico significa um aumento dos impactos ambientais.

O aumento da capacidade de consumir dos ricos e o rápido crescimento populacional entre os pobres criam pressões insustentáveis para o meio ambiente e barreiras ao desenvolvimento econômico que, para ser obtido, requer um redirecionamento dos atuais padrões de produção e consumo que estão pouco comprometidos com o desenvolvimento sustentável tanto em escala local como global (RIBEMBOIM, 2001).

A universalidade não pode ser considerada para impor uma estratégia única e obrigações equivalentes aos países do Norte e do Sul, pois as diferenças existentes entre eles, em termos de riqueza, capacidades tecnológicas, modos de vida e problemas sociais são muito distantes. Portanto, cada país deve formular suas próprias respostas aos problemas planetários, em função da especificidade de seus ecossistemas, da sua cultura e das suas circunstâncias locais (SACHS, 2007).

O padrão de desenvolvimento da sociedade contemporânea, segundo Viegas (2010), caracteriza-se centralmente pela exploração excessiva e constante dos recursos naturais, pela geração maciça de resíduos e pela crescente exclusão social, advinda do uso desigual das riquezas produzidas, constatando assim, um impasse entre o meio ambiente e o desenvolvimento ao não se estabelecerem patamares sustentáveis de produção e consumo.

Para Bourdieu (2007), a nova lógica da economia substitui a moral ascética da produção e do acúmulo, baseada na abstinência, sobriedade, poupança e calculismo, por uma moral hedonista do consumo, baseada no crédito, despesa e fruição. Segundo o autor, essa economia:

deseja um mundo social que julga os homens tanto por suas
capacidades de consumo, seu standing e estilo de vida, quanto por
suas capacidades de produção. Ela encontra seus porta-vozes
convencidos na nova burguesia dos vendedores de bens e serviços
simbólicos, empresários e quadros das empresas de turismo e
jornalismo, de imprensa e cinema, de moda e publicidade, de
decoração e promoção imobiliária: por seus conselhos
dissimuladamente imperativos e pelo exemplo de uma arte de viver que
eles vivem como exemplar, os novos taste makers propõem uma moral
reduzida a uma arte de consumir, gastar e usufruir (BORDIEU, 2007,
p. 291).

Seria necessário repensar as bases conceituais de um novo modelo social e novas estratégias de implementação sob a ótica do desenvolvimento sustentável. Essa nova concepção de política de desenvolvimento é uma proposta fundamental de equacionamento da crise socioambiental, constituindo-se em um processo de transição 
em direção ao estabelecimento de uma sociedade sustentável, pressupondo uma reconstrução integral da sociedade contemporânea (VIEGAS, 2010).

A característica do consumo na sociedade começa a apresentar alguns sintomas de que o caminho a ser percorrido pelo desenvolvimento para se obter um crescimento econômico contínuo está começando a mostrar sinais de fragilidade no que tange as perspectivas para as futuras gerações.

O crescimento econômico é uma condição necessária para o desenvolvimento, porém não é suficiente para se alcançar uma vida melhor. Os objetivos do desenvolvimento vão além da mera multiplicação da riqueza material, já o crescimento, mesmo que acelerado, deixa de ser sinônimo de desenvolvimento se ele não amplia o emprego, se não reduz a pobreza, se não atenua as desigualdades e se não minimiza os impactos ambientais (SACHS, 2008).

Sachs (2008), afirma em sua obra que:

[...] o crescimento econômico, embora necessário, tem um valor apenas instrumental; o desenvolvimento não pode ocorrer sem crescimento, no entanto, o crescimento não garante por si só o desenvolvimento; o crescimento pode, da mesma forma, estimular 0 mau desenvolvimento, processo no qual o crescimento do PIB é acompanhado de desigualdades sociais, desemprego e pobreza crescentes (SACHS, 2008, p. 71).

Para o autor, no nível econômico, o desenvolvimento deve tratar de diversificar e complexificar as estruturas produtivas, logrando ao mesmo tempo, incrementos significativos e contínuos da produtividade de trabalho, base do aumento do bem-estar. No nível social, deve promover a homogeneização da sociedade, reduzindo as distâncias sociais que separam as diferentes camadas da população (SACHS, 2008).

Níveis de crescimento continuado, voltados para a satisfação de demandas por bens de consumo não essenciais se mostram incompatíveis com um processo de desenvolvimento ecologicamente sustentável, acarretando a necessidade de mudanças nos padrões de consumo de bens materiais (MORAIS e COSTA, 2010)

O crescimento do PIB caminha lado a lado com uma pressão crescente sobre a biodiversidade, mudanças climáticas e destruição dos recursos que permitem ao homem sobreviver em áreas localizadas fora do eixo do mercado. Para Alier (2012), o consumismo excessivo das pessoas de classe alta e média não é apenas uma ameaça para outras espécies e gerações futuras, pois já está privando os pobres do acesso a uma divisão justa dos recursos e do espaço ambiental.

Neste contexto complexo, as estratégias de desenvolvimento dos países acabam por abarcar diferentes formas de aproximação ao problema, nas quais a coerência entre modelo de produção e consumo e preservação ambiental não necessariamente existe. 
Conceber formas promover o bem-estar humano sem que isso prejudique sua capacidade de recursos naturais é o grande desafio para os novos modelos de desenvolvimento.

O Brasil enfrenta, portanto, o desafio de lutar contra a pobreza ao mesmo tempo em que considere seus custos ambientais envolvidos como parte das suas políticas de desenvolvimento. Não é possível negar o progresso econômico, mas as políticas públicas podem orientar esse progresso com 0 uso de novas tecnologias. Exemplificando, todas as pessoas têm o direito de ter acesso à iluminação, independentemente de sua condição social, no entanto, atualmente existem lâmpadas que iluminam tão bem ou até mesmo melhor e usam dez vezes menos eletricidade, além de durarem mais tempo do que as antigas. Sendo assim, o próximo item aborda o papel do Estado e de suas políticas para a sustentabilidade.

\subsection{CONSUMO, MEIO AMBIENTE E POLÍTICAS PÚBLICAS}

$\mathrm{O}$ ato de consumir representa um grande passo para o desenvolvimento quando as pessoas passam a ter maiores possibilidades de acesso a uma alimentação, a uma moradia, saúde, educação etc. Porém, ao mesmo passo, o consumo quando começa a considerar os bens supérfluos, deixa de trazer o equilíbrio para o desenvolvimento e passa a representar uma ameaça a disponibilidade de recursos naturais existentes. Neste sentido, as políticas públicas passam a desempenhar um papel primordial para uma mudança de modelo de consumo que cause menos dano ao meio ambiente.

O impacto ambiental do consumo surge como uma questão de política ambiental relacionada as propostas de desenvolvimento sustentável, requerendo uma mobilização de processos políticos que visem transformações produtivas e de conhecimento para atingir metas sustentáveis. A relação entre o Estado, as empresas e a sociedade envolve um novo compromisso ético de reconhecimento mútuo como partes constituintes tanto dos problemas quanto das soluções ambientais (OLIVEIRA et al, 2011).

A partir deste reconhecimento mútuo seria possível que as políticas públicas considerem as causas e os impactos que os padrões e níveis de consumo atuais causam ao meio ambiente, de modo que se possa direcionar as regulamentações e promover estruturas de incentivos para os atores envolvidos no processo ao implementar ações que visem tornar o consumo como um ato de cidadania, de estratégia de preservação ambiental e de desenvolvimento econômico e social a partir de inovações institucionais e sociais (OLIVEIRA et al, 2011). 
Portilho (2005) cita Paavola (2001b) para defender a ideia de que as ações e intervenções públicas podem ser mais eficazes do que as estratégias individuais e comportamentais. As ações públicas poderiam provocar mudanças no impacto ambiental do consumo com um custo menor do que o de ações individuais, através da melhoria dos transportes públicos em detrimento do transporte individual, por exemplo.

Os problemas ambientais requerem que o Estado incorpore práticas ambientais em suas políticas públicas por meio de instrumentos de gestão ambiental criados para atingir os efeitos ambientais benéficos. Para isso, seria necessário que os órgãos públicos desenvolvessem ferramentas que minimizem os impactos ambientais gerenciando as entidades por intermédio da criação de parâmetros de sustentabilidade ambiental (SOUSA; CARVALHO, 2015).

Para Sousa e Carvalho (2015), a construção de uma nova cultura organizacional pública, voltada para inserção de critérios sociais e ambientais em sua rotina administrativa, pode acarretar em um diferencial estratégico, onde os agentes públicos, por meio da mudança de valores e práticas, se transformam em novos atores e contribuem para um meio ambiente mais equilibrado.

No entanto, o desenvolvimento não se faz somente com políticas ambientais e rotinas administrativas que incorporem a preservação ambiental nas práticas organizacionais. O desafio já citado anteriormente, de promover o desenvolvimento com distribuição de riqueza sem esgotar os recursos naturais, leva a uma ação mais ampla do Estado e a articulação entre políticas de diversos setores e níveis federativos.

Segundo Cavalcanti (2002), o Brasil deveria enfrentar o desafio de lutar contra a pobreza fazendo simultaneamente uma correta consideração dos custos ambientais envolvidos como parte das políticas de desenvolvimento.

Porém, é preciso levar em conta que a questão ambiental que deve ser examinada em relação a iniciativas de desenvolvimento não deve ser reduzida simplesmente a exploração de recursos não renováveis de maneira parcimoniosa. Para Cavalcanti (2002), uma visão distinta do processo econômico, levando em conta a dimensão biofísica, as leis e princípios da natureza, é o requerido. A elaboração de regras para um desenvolvimento sustentável deveria reconhecer o fato de que a ciência econômica convencional não considera a base ecológica do sistema econômico dentro de ser arcabouço analítico, levando assim à crença no crescimento ilimitado. Ainda segundo esse autor, a ideia de sustentabilidade implica uma limitação definida nas possibilidades de crescimento, por isso o fundamento de se agregar preocupações ecológicas às políticas públicas.

Uma política de desenvolvimento, em busca de uma sociedade sustentável, não poderia desprezar as relações entre o homem e a natureza que ditam o que é possível 
em face do que é desejável. Aqui, encontra-se um dos grandes desafios do desenvolvimento sustentável: elaborar políticas que possam levar a uma melhoria real das condições de vida das pessoas pobres sem perturbar as funções ecossistêmicas essenciais (CAVALCANTI, 2002).

Neste sentido, Cavalcanti (2002) salienta que no contexto de políticas que persigam o desenvolvimento sustentável deve estar o fato de que o crescimento significa sempre alguma forma de degradação do meio ambiente, não devendo confundir desenvolvimento com crescimento, pois em discursos sobre desenvolvimento em um país como o Brasil subtende-se sempre aumentar a renda per capita indefinidamente e isto representa crescimento, o que de fato, seria muito bom, caso o último implicasse redução verdadeira e permanente ou eliminação da pobreza.

A política de governo para o desenvolvimento sustentável não pode desconhecer a capacidade de suporte, a resiliência, os limites e a sustentabilidade em termos de relações entre o processo econômico e o ecossistema. Ela tem de ligar iniciativas públicas com as coordenadas estabelecidas pelas funções e processos naturais que indicam os limites do possível (CAVALCANTI, 2002).

O Estado pode direcionar seus esforços em diferentes vertentes para auxiliar no alcance do desenvolvimento sustentável. Para Silva (2011), o papel do governo é o de regular e fiscalizar as atividades gerais que estejam desviadas desse objetivo, bem como financiar e fomentar o surgimento de alternativas capazes de sustentar a ação humana quanto ao meio ambiente, visando melhor organizar a sociedade.

Os hábitos de consumo e os estilos de vida merecem uma atenção especial nas políticas de governo com vistas a sustentabilidade. De um lado, níveis excessivos de consumo de bens e serviços devem ser contidos e de outro, a persuasão para que se consuma mais, nutrida pelos meios de comunicação, deve ser revista e posta dentro dos parâmetros de prudência ecológica indispensáveis para a sustentabilidade (CAVALCANTI, 2002).

O deslocamento das atenções e estratégias políticas para o campo do consumo, segundo Portilho (2010), pode trazer a possibilidade de ambientalização e politização da esfera individual e cotidiana, aumentando a participação dos cidadãos comuns na questão ambiental e produzindo novas formas de fazer políticas e de existir enquanto sujeito político.

Considerações ambientais deveriam ser misturadas com propostas de equidade social, eficiência econômica e factibilidade política. A formulação de políticas para a sustentabilidade em todos os setores da ação governamental deveria apoiar-se em critérios biofísicos de uso sustentável da natureza, combinados com instrumentos para 
a correção dos desequilíbrios sócio econômicos e a promoção do bem-estar da população (CAVALCANTI, 2002).

É notável, a partir desse ponto, que as políticas públicas se tornam determinantes para um processo de desenvolvimento sustentável, pois nos compele a trabalhar com ferramentas diversas da economia tradicional, de modo que seja eliminado o crescimento obtido ao custo de elevadas externalidades negativas, tanto sociais como ambientais (MACIEL, 2011).

Foi quando o mercado, como força quase exclusiva da condução da economia, entrou em crise, no período entre as duas guerras mundiais, que o Estado e os mercados passaram a promover em conjunto o desenvolvimento. A ação política dos governos no campo da economia expressa-se através de ação reguladora e pela participação direta do Estado na economia. É a partir disso que aparecem as chamadas políticas governamentais, que mais tarde foram entendidas como políticas públicas (HEIDEMANN, 2009).

Segundo Heidemann (2009), o desenvolvimento de uma sociedade resulta de decisões formuladas e implementadas pelos governos dos Estados nacionais, subnacionais e supranacionais em conjunto com as demais forças vivas da sociedade, sobretudo as forças de mercado. São essas decisões e ações do governo e de outros atores sociais que constituem as políticas públicas.

Na medida em que as políticas públicas visem promover o desenvolvimento, não podem mais ater-se à visão que o compreende como crescimento econômico, sendo assim, necessária a integração das demais dimensões que passaram a integrá-la, como a questão social e ambiental, por exemplo (MACIEL, 2011).

Segundo Maciel (2011), deve-se buscar transformar as dimensões do desenvolvimento sustentável em critérios objetivos de políticas públicas, tornando a proteção do meio ambiente, um elemento fundamental no processo de desenvolvimento.

Segundo o PNUMA (2011), as políticas públicas podem trazer reais benefícios na busca pelo desenvolvimento, como por exemplo, a responsabilidade estendida do produtor ou depósitos retornáveis no setor agrícola, os quais podem ajudar a promover a manufatura de circuito fechado e prolongar os ciclos de vida dos produtos, bem como gerar mais empregos nas áreas de manutenção, reparos, remanufatura e reciclagem.

Além disso, as políticas públicas têm um papel central para que o desenvolvimento alcance todas as camadas sociais através de políticas de transferência de renda, de investimento em serviços básicos, de capacitação para o emprego entre outras (BOSCHI; GAITÁN, 2008). 
Porém, segundo Marques e Santos (2011), no processo de elaboração de políticas públicas para o desenvolvimento e na definição do campo de ação dos gestores públicos, encontram-se alguns princípios aos quais os formuladores das políticas de desenvolvimento devem estar atentos: a hierarquia de objetivos, a abrangência da política e a sua efetivação. Segundo os autores, as propostas indicadas devem procurar maximizar as potencialidades e minimizar as deficiências, com o intuito de se obter o máximo de resultado com melhor alocação possível dos esforços e dos recursos, tornando as políticas públicas em principais vetores do desenvolvimento. 


\section{MÉTODO DE PESQUISA}

Uma pesquisa é sempre, de alguma forma, um relato de longa viagem empreendida por um sujeito cujo olhar vasculha lugares muitas vezes já visitados. Nada de absolutamente original, portanto, mas um modo diferente de olhar e pensar determinada realidade a partir de uma experiência e de uma apropriação do conhecimento que são, aí sim, bastante pessoais (DUARTE, 2002).

Para construir a dissertação sobre a forma como o consumo sustentável é tratado dentro da estratégia brasileira de desenvolvimento será realizado um estudo de natureza qualitativa, com roteiro semiestruturado para as entrevistas.

Buscou-se ao longo do trabalho, categorias que pudessem estabelecer a relação entre desenvolvimento e consumo nas políticas públicas brasileiras. Para isso, caracterizou-se a experiência brasileira em quatro categorias: I) o aumento da renda da população através dos programas de transferência de renda; II) recursos naturais; III) programas educacionais; e IV) geração de resíduos. A escolha dessas categorias se deu em função da análise teórica previamente exposta na dissertação e de acordo com as respostas dos entrevistados. Além disso, essas categorias se apresentam como fundamentais para a estratégia de desenvolvimento sustentável brasileira.

As principais fontes de dados para este trabalho foram o Instituto Brasileiro de Geografia e Estatística (IBGE); Instituto de Pesquisa Econômica Aplicada (IPEA); Banco Nacional de Desenvolvimento (BNDES); Banco Central Brasileiro (BACEN); Fundo Monetário Internacional (FMI); Banco Mundial (WB); Agência Nacional do Petróleo, Gás Natural e Biocombustíveis; Ministério das Cidades; Ministério do Planejamento, Orçamento e Gestão (MPOG); Ministério da Ciência, Tecnologia e Inovação (MCTI); Programa das Nações Unidas para o Desenvolvimento (PNUD) e Programa das Nações Unidas para o Meio Ambiente (PNUMA).

As entrevistas buscaram compreender o conhecimento e a articulação de ideias dos entrevistados sobre consumo e sustentabilidade. A escolha dos entrevistados (conforme quadro abaixo) se deu pelo papel que eles desempenham na articulação das principais políticas públicas do governo. As entrevistas foram presenciais, duraram em média vinte minutos e foram todas gravadas com consentimento dos respondentes. 


\begin{tabular}{|c|c|c|c|}
\hline Nome & Cargo & Órgão & $\begin{array}{c}\text { Data da } \\
\text { Entrevista }\end{array}$ \\
\hline $\begin{array}{l}\text { Haroldo de Oliveira } \\
\text { Machado Filho }\end{array}$ & Assessor Sênior & $\begin{array}{c}\text { Programa das } \\
\text { Nações Unidas para } \\
\text { o Desenvolvimento }\end{array}$ & $28 / 01 / 16$ \\
\hline Mario Mottin & $\begin{array}{c}\text { Chefe de } \\
\text { Coordenação } \\
\text { Geral de } \\
\text { Desenvolvimento } \\
\text { Sustentável }\end{array}$ & $\begin{array}{c}\text { Ministério das } \\
\text { Relações Exteriores }\end{array}$ & 28/01/16 \\
\hline $\begin{array}{c}\text { Ian Ramalho } \\
\text { Guerriero }\end{array}$ & $\begin{array}{l}\text { Diretor da } \\
\text { Secretaria do } \\
\text { Programa de } \\
\text { Aceleração do } \\
\text { Crescimento }\end{array}$ & $\begin{array}{c}\text { Ministério do } \\
\text { Planejamento, } \\
\text { Orçamento e Gestão }\end{array}$ & $27 / 01 / 16$ \\
\hline $\begin{array}{c}\text { Raquel Breda dos } \\
\text { Santos }\end{array}$ & $\begin{array}{c}\text { Diretora do } \\
\text { Departamento de } \\
\text { Produção e } \\
\text { Consumo } \\
\text { Sustentáveis }\end{array}$ & $\begin{array}{c}\text { Ministério do Meio } \\
\text { Ambiente }\end{array}$ & $27 / 01 / 16$ \\
\hline Fábio Larotonda & $\begin{array}{c}\text { Assessor da } \\
\text { Secretaria de } \\
\text { Políticas e } \\
\text { Programas de } \\
\text { Pesquisa e } \\
\text { Desenvolvimento }\end{array}$ & $\begin{array}{c}\text { Ministério da Ciência, } \\
\text { Tecnologia e } \\
\text { Inovação }\end{array}$ & 29/01/16 \\
\hline Renato Rosenberg & $\begin{array}{l}\text { Assessor da } \\
\text { Secretaria do } \\
\text { Programa de } \\
\text { Aceleração do } \\
\text { Crescimento }\end{array}$ & $\begin{array}{c}\text { Ministério do } \\
\text { Planejamento, } \\
\text { Orçamento e Gestão }\end{array}$ & $28 / 01 / 16$ \\
\hline
\end{tabular}

Quadro 1: Relação de Entrevistados.

Fonte: Elaboração própria.

O roteiro da entrevista foi elaborado visando compreender melhor a relação entre o desenvolvimento e a sustentabilidade através da sua inter-relação com a questão do consumo. Para isso, foram elaboradas perguntas mais gerais sobre o tema e logo em 
seguida, perguntas mais específicas de acordo com o órgão e a função exercida, segundo o apêndice A desta dissertação.

Após a coleta de dados foram realizadas uma análise e uma interpretação dos resultados obtidos. Segundo Gil (1999), a análise serve para organizar e sumariar os dados de forma que possa possibilitar o fornecimento de respostas ao problema proposto para a investigação, enquanto a interpretação procura dar um sentido mais amplo para as repostas, seguindo outros conhecimentos obtidos anteriormente.

A organização da análise se deu segundo Laurence Bardin (1977), a qual organiza a análise de conteúdo em três categorias: pré-análise; exploração do material; e tratamento de resultados, inferência e interpretação. Para a autora, a análise de conteúdo pode ser caracterizada como

\begin{abstract}
um conjunto de técnicas de análise das comunicações visando obter, por procedimentos, sistemáticos e objetivos de descrição do conteúdo das mensagens, indicadores (quantitativos ou não) que permitam a inferência de conhecimentos relativos às condições de produção/recepção (variáveis inferidas) destas mensagens.
\end{abstract}

Desse modo, a pré-análise foi a fase onde foi organizado o material a ser elaborado com o objetivo de torná-lo operacional e sistematizar as ideias iniciais. A exploração do material consistiu na definição das categorias a serem analisadas de modo que os dados fossem transformados de forma organizada e agregados em unidades para permitir uma descrição das características pertinentes do conteúdo. $O$ tratamento de resultados, inferência e interpretação consistiu no tratamento estatístico simples dos resultados, permitindo a elaboração de gráficos que condensam e destacam as informações fornecidas para análise. As entrevistas seguiram o mesmo procedimento, sendo a análise guiada pelo quadro 1. 


\section{EXPERIÊNCIA BRASILEIRA NA RELAÇÃO ENTRE CONSUMO E DESENVOLVIMENTO}

A evolução da relação entre sustentabilidade e desenvolvimento está presente há muitos anos, sobretudo na década de 70 quando houve uma maior concentração dos problemas ambientais e os países desenvolvidos começaram a implementar políticas públicas visando essa relação. De início houve uma resistência dos países em desenvolvimento por acreditarem que seria uma limitação a algum direito ao desenvolvimento. De fato, pode-se dizer que foi uma discussão que levou a uma polarização Norte-Sul que perdura até hoje. Somente na Rio 92 que a questão socioambiental começou a entrar em pauta nos debates sobre desenvolvimento. A partir disso, a percepção e os problemas aumentaram, principalmente por causa dos impactos causados pelo efeito estufa. Somente em 2012 que o desenvolvimento sustentável passou a ser a principal questão, analisando a sustentabilidade a partir de três dimensões: social, ambiental e econômica (MACHADO, 2016 - entrevista).

Para o entrevistado Mario Mottin (2016), na Conferência de Estocolmo houve pela primeira vez o choque claro entre o direito ao desenvolvimento e uma perspectiva mais ambientalista. Da conferência aos dias atuais evolui o pensamento para o desenvolvimento sustentável, um conceito multifuncional, multifacetado que privilegia a integração das áreas e não mais o seu funcionamento de forma independente. Dessa forma, há a necessidade de um esforço em prol do desenvolvimento, mas sem que necessariamente cause danos ao meio ambiente e ao bem-estar social.

Neste sentido, o desenvolvimento sustentável, segundo o entrevistado Renato Rosenberg (2016) pode ser considerado um conjunto de decisões, de propostas de inclusão dessa variável no planejamento e execução das ações do governo, considerando mais possibilidade de gestão de conservação. Para a entrevistada Raquel Breda (2016), no desenvolvimento sustentável há uma preocupação que vai além do crescimento econômico, há uma maior preocupação com as pessoas, com os valores sociais e culturais, garantindo assim, a conservação do meio ambiente e a durabilidade do desenvolvimento.

Para o entrevistado lan Ramalho (2016), o desenvolvimento é um processo de transformação produtiva da sociedade, o capitalismo, por sua vez, faz o processo de transformação produtiva com sentido de progresso técnico, produzindo cada vez mais com menos recursos e de forma cada vez mais barata. Quando a preocupação ambiental se mistura com a dinâmica capitalista, cria-se uma pressão para que o capitalismo se adapte, criando inovações e criando produtos que se adaptem a esse aspecto. 
Segundo o entrevistado Mario Mottin (2016), durante as negociações da nova agenda de desenvolvimento das Nações Unidas, em 2015, o Brasil se estruturou nacionalmente de forma bastante sofisticada. Contou com a coordenação nacional dentro do governo com o envolvimento de 25 ministérios, além de diálogos com a sociedade civil. A questão da mudança dos padrões de consumo e produção foi considerada como fundamental na etapa de consultas e formação da posição brasileira. Todos os países têm muito claro durante a negociação que a participação do Brasil foi de extrema importância na própria formatação dos conceitos mais internos, mais básicos, assim como outras questões que são a espinha dorsal da agenda.

Segundo a entrevistada Raquel Breda (2016), a questão da transversalidade é fundamental para as políticas públicas brasileiras, pois é através da coordenação e articulação entre todos os setores que é possível demonstrar a importância das questões de conservação do meio ambiente e desenvolvimento sustentável.

De acordo com o entrevistado Haroldo Machado (2016), a pluralidade que o Brasil traz ao acreditar no multilateralismo é muito importante, pois o país consegue colocar a temática da sustentabilidade na politics internacional. É por meio de um sistema multilateral de relações internacionais que é possível dar o mínimo de tratamento para os problemas globais.

O governo tem o poder de intervir com várias estratégias de ação, de âmbitos diferentes, para atender às necessidades e problemas da sociedade e seu meio. As políticas públicas, segundo Corzo (2013), são ações governamentais com objetivos de interesse público decorrentes de decisões baseadas em um processo de diagnóstico e análise de viabilidade para assistência eficaz a questões públicas específicas.

Tradicionalmente, sobretudo no ocidente, países lograram alcançar níveis de satisfação das necessidades básicas da população utilizando políticas públicas para incentivar o consumo. A visão adotada é que esse incentivo promove uma ampliação de acesso a serviços públicos e com isso, promove a inclusão. A partir disso, os cidadãos passam a exigir cada vez mais boas condições de trabalho e de vida. Porém, esse modelo entra em colapso a partir do momento em que o consumo se sobrepõe ao bem-estar, quando o individualismo começa a falar mais alto que o interesse coletivo. Segundo o entrevistado Haroldo Machado (2016), o problema no Brasil é não ter esse equilíbrio entre o individual e o coletivo e, portanto, faz-se o desafio de encontrar um equilíbrio entre a renda, a inclusão social, os serviços públicos, a sensação de bemestar e segurança.

O Brasil, ao longo dos últimos anos tem utilizado políticas públicas que tem estimulado o consumo da população como uma das formas de obtenção de crescimento econômico. Políticas públicas foram elaboradas e implementadas para que houvesse 
um aumento da condição de renda das pessoas mais pobres, tirando milhares delas da linha pobreza.

Desde o governo Luís Inácio Lula da Silva (2003-2010), o modelo de desenvolvimento brasileiro encontrava-se direcionado para o consumo através de programas de transferências de renda e direcionamento de recursos para atendimento das necessidades básicas da população. O princípio era o de estimular o consumo com vistas a conseguir com que as empresas produzissem e investissem mais. Atualmente, o governo da presidente Dilma Rousseff (2011- atual) mantém esse modelo e, ao mesmo tempo, busca a qualidade do crédito para tentar manter um crescimento econômico satisfatório.

Para que esse modelo possa dar continuidade a longo prazo, são necessários dois elementos que se interconectam: o concurso de um vigoroso processo de inovação, conduzido pelo setor empresarial, por instituições públicas e por outras instâncias da sociedade; e o concurso de uma decidida política de uso sustentável de recursos naturais que busque compatibilizar o progresso material da população com o máximo respeito ao meio ambiente e à conservação da natureza (MCTI, 2010).

A estratégia de desenvolvimento contida nos Planos Plurianuais (PPA) do governo brasileiro aponta um modelo de desenvolvimento sustentável, bem distribuído regionalmente, que busca a igualdade social com educação de qualidade, a produção de conhecimento, a inovação tecnológica e a sustentabilidade ambiental, sem deixar de lado seu caráter de nação democrática e soberana, que defende os direitos humanos e a liberdade, a paz e o desenvolvimento no mundo.

O primeiro PPA, elaborado para o período correspondente entre 2004 e 2007, tomava como base o fortalecimento do mercado interno mediante a conformação de um mercado de massas apoiado em aumentos reais do salário mínimo, políticas de transferências de renda e redução de desigualdades, combinados com o controle da inflação. A intenção era a de proporcionar a inclusão de milhares de famílias nos circuitos de produção e consumo para, consequentemente, obter ganhos de escala que contribuiriam com o aumento da produtividade, que seria transmitido às famílias trabalhadoras, formando assim, um círculo virtuoso de inclusão social.

O PPA 2008-2011 continuou a reforçar o fortalecimento do mercado interno com redução de desigualdades por meio da aceleração dos investimentos em educação e infraestrutura econômica e social, destacando-se o Programa de Aceleração do Crescimento (PAC), o Plano de Desenvolvimento da Educação (PDE), e pelo Programa Minha Casa, Minha Vida.

A partir do PPA 2012-2015, a execução das políticas públicas passa a ser organizada em torno de três grandes áreas: o Brasil Sem Miséria, o PAC 2 e a política 
de desenvolvimento produtivo com programas fundamentais como o Programa Nacional de Acesso ao Ensino Técnico e Emprego (Pronatec) e o Programa Ciências sem Fronteiras (CsF). Esta trajetória busca consolidar um padrão de transformações estruturais, orientada pela priorização da dimensão social, apresentadas em cinco dimensões: social, econômica, ambiental, territorial e político-institucional.

Com relação à dimensão ambiental, foco deste trabalho, o desenvolvimento, conforme exposto no PPA, significa que o uso dos recursos naturais para geração de riqueza e renda não deve se dissociar da promoção da qualidade de vida e da sustentabilidade, sendo capaz de compatibilizar a capacidade de distribuir os benefícios de modo mais equitativo, com o compromisso de abandonar práticas que causem danos ao meio ambiente, estabelecendo relações equilibradas, mutuamente benéficas e permanentes entre sociedade e natureza.

A estratégia do PPA 2012-2015 vincula as transformações sociais à ampliação da atividade econômica com preservação ambiental, por intermédio da constituição de um grande mercado de consumo de massas na expectativa de promover um círculo virtuoso ancorado nos efeitos desse mercado sobre a expansão do investimento, da produtividade e dos rendimentos.

Essa expansão do mercado de consumo de massas, segundo Bielschowsky (2012), ocorre devido aos seguintes fatores:

i) rápido aumento na massa salarial, por volume de emprego e elevação dos rendimentos do trabalho; ii) transferências de renda à população pobre, por efeito de políticas sociais como o impacto do aumento do salário mínimo sobre as pensões e o "Bolsa Família"; iii) estabilidade ou queda nos preços dos bens industriais de consumo popular por valorização cambial e por importação de bens da China e da Ásia; iv) forte ampliação do crédito ao consumo e acesso da população de baixa renda ao mesmo (BIELSCHOWSKY, 2012, p. 738).

Ainda segundo esse autor, o círculo virtuoso desse modelo de produção e consumo de massa opera da seguinte maneira:

i) o aumento do consumo provoca a expansão dos investimentos, que se traduzem em aumento de produtividade e competitividade pelas vias de mais equipamentos por trabalhador, conhecimento, aprendizado e inovação e economias de escala (da produção em massa); ii) a elevação da produtividade transmite-se equilibradamente a lucros e rendimentos das famílias trabalhadoras pelo aumento de salários, redução dos preços dos bens e serviços e aumento dos gastos sociais; iii) esses rendimentos transformam-se em consumo popular continuamente ampliado; iv) essa ampliação provoca a expansão dos investimentos (BIELSCHOWSKY, 2012, p. 739).

Segundo o Plano, a taxa média estimada para a expansão do consumo das famílias nos próximos anos deve ficar em torno de $5 \%$ aa, liderada pela expansão da 
renda gerada pelos investimentos. As estimativas estão baseadas nas respostas das despesas de consumo à manutenção do ciclo virtuoso do crescimento, que provoca expansão quantitativa e qualitativa no mercado de trabalho, com queda na taxa de desemprego e elevação na formalização dos postos de trabalho e nos rendimentos auferidos pelos trabalhadores.

A atual estratégia parece consolidar a visão de que o desenvolvimento já não está mais associado ao crescimento econômico, tendo como parâmetro fundamental a redução das desigualdades com sustentabilidade. A sustentabilidade do processo de desenvolvimento impõe que os avanços socioeconômicos sejam complementados, ao invés de se oporem, pela preservação e pelo uso sustentável do meio ambiente (MPOG, 2014).

A continuidade do atual ciclo de crescimento da economia brasileira e a construção de um novo padrão de desenvolvimento sustentável demandam uma maior centralidade da política de desenvolvimento científico e tecnológico e de inovação. É papel do Ministério da Ciência, Tecnologia e Informação, através da Estratégia Nacional de Ciência, Tecnologia e Inovação - ENCTI, impulsionar essa mudança apoiando os setores portadores de futuro, preparando o Brasil para a economia do conhecimento e da informação, auxiliando na transição para uma economia verde e criativa e contribuindo para a inclusão produtiva. Inaugura-se, portanto, um processo que está se firmando como um novo ciclo de desenvolvimento, baseado no crescimento com redistribuição de renda e na incorporação de grande contingente populacional ao mercado de consumo de massa, preservando os aspectos essenciais da sustentabilidade (MCTI, 2012).

A ENCTI tenta contornar a situação de defasagem em ciência e tecnologia que separa o país das nações mais desenvolvidas, expandir a liderança brasileira em temas ligados à sustentabilidade ambiental e a superar as desigualdades sociais e regionais.

Segundo o entrevistado Fábio Larotonda (2016), a questão da sustentabilidade já era preocupação do governo antes mesmo da elaboração da ENCTI. Entre 2007 e 2010, houve a elaboração de um plano de ação para ciência e tecnologia para o desenvolvimento nacional em que surgiram diversas questões referentes à sustentabilidade. O objetivo era usar a ciência e a tecnologia como eixo estruturante do Brasil para enfrentar seus desafios e para isso, a pesquisa foi o meio utilizado para distribuir entre os diversos órgãos do governo esse conceito agregando diretrizes gerais sobre como proceder.

Atualmente, o Brasil está desenvolvendo a nova ENCTI propondo ações que visem mitigar e proteger qualquer dano ao meio ambiente. Uma das ações dessa nova estratégia é aumentar a produtividade sem aumentar o espaço já utilizado, ou seja, 
produzir mais no mesmo espaço. Além disso, o governo busca oportunidades para fomentar ações que levem a liderança brasileira na questão da sustentabilidade em determinados assuntos, por exemplo a questão da saúde dos trópicos. Doenças que só existem na nossa região são uma oportunidade para ampliar pesquisas específicas sobre o assunto, pois não há interesse de outros países em pesquisar doenças as quais eles não estão sendo afetados (LAROTONDA, 2016 - entrevista).

Mas não é tão recente a preocupação do governo brasileiro com relação a questão do consumo sustentável em seu processo de desenvolvimento. Em 1996 ocorreu a primeira iniciativa focada no assunto, o workshop "Produção e Consumo Sustentáveis: Padrões e Políticas", em parceria com o governo da Noruega. Em 1998, ocorreu o "Interregional Expert Group Meeting on Consumers Protection and Sustainability", em São Paulo, que resultou em um documento com propostas de ampliação da Diretriz de Defesa dos Consumidores das Nações Unidas. Em 1999 surge a Agenda Ambiental da Administração Pública (A3P) buscando estratégias inovadoras que repensem os atuais padrões de produção e consumo, os objetivos econômicos, inserindo componentes sociais e ambientais. No ano de 2002, o tema ganha relevância nacional e é incluído na Agenda 21 Brasileira com o objetivo denominado "produção e consumo sustentáveis contra a cultura do desperdício". Em 2007, o Brasil adere ao Processo de Marrakesh da ONU e ocorre a "Mesa Redonda Nacional sobre produção e consumo sustentáveis" em São Paulo. No ano seguinte é criado através da Portaria no 44, de 13 de fevereiro de 2008, o Comitê Gestor Nacional de Produção e Consumo Sustentáveis (CGPCS) para ampliar o debate e identificar causas que pudessem levar o país a buscar padrões mais sustentáveis de produção e de consumo. Em 2011 é lançado o Plano de Ação para Produção e Consumo Sustentáveis (PPCS) como documento que guiaria as ações do governo, do setor produtivo e da sociedade com medidas sobre educação para o desenvolvimento sustentável, compras públicas sustentáveis, agenda ambiental para a administração pública, reciclagem de resíduos sólidos, varejo sustentável e construção sustentável.

A posição oficial do país é a de que a adoção de padrões de produção e consumo sustentáveis conduzirá a uma profunda transformação nas economias e nas sociedades ao redor do mundo, podendo inclusive, obter um papel crucial na luta contra a pobreza.

Para o MMA (2014), em seu primeiro ciclo de implementação, o PPCS representou um novo patamar no modelo de desenvolvimento brasileiro, no qual o crescimento econômico precisa ser equitativo e inclusivo, reduzindo as desigualdades e melhorando a qualidade de vida das pessoas ao mesmo tempo em que promove a gestão e a conservação dos recursos naturais e dos ecossistemas. 
Primeiramente as ações foram focadas em medidas relativas ao consumo com o apoio de parceiros estratégicos. Buscou-se identificar e fortalecer as iniciativas já existentes e melhores práticas no âmbito governamental e no setor privado que contribuíram para a consecução das metas estabelecidas em todas as prioridades. Além disso, outras ações e iniciativas foram realizadas fora do contexto do Plano e contribuíram para seus objetivos, como os programas de eficiência energética, por exemplo.

Dentre os principais resultados desse primeiro ciclo de implementação do PPCS destacam-se no âmbito da educação para consumo sustentável, cursos semipresenciais do Programa de Educação Ambiental e Agricultura Familiar (PEAAF), em parceria com 16 instituições de 11 estados que formaram mais de 1.700 pessoas com o objetivo de estimular práticas produtivas mais sustentáveis e mais justas no campo, além da regularização ambiental das propriedades rurais; repasse financeiro pelo Fundo Nacional de Desenvolvimento da Educação (FNDE) para promover ações voltadas à melhoria da qualidade de ensino e apoiar escolas públicas na adoção de critérios de sustentabilidade socioambiental; a 4ª Conferência Infanto-juvenil de Meio Ambiente, realizada em 2013, que mobilizou mais de nove milhões de pessoas em todo país, envolvendo quase 17.500 escolas; além de várias ações de informação e comunicação que mobilizaram um número expressivo de pessoas, como por exemplo, as campanhas de conscientização e mobilização sobre "Consumo Consciente de Embalagem", "Saco é um Saco", "Vamos Tirar o Planeta do Sufoco" e "Separe o Lixo e Acerte na Lata".

No âmbito das compras públicas sustentáveis, que saíram de $\mathrm{R} \$ 13,5$ milhões para uma participação de $\mathrm{R} \$ 40,4$ milhões de aquisições dos Órgãos do Sistema Integrado de Administração de Serviços Gerais (SISG), significando um crescimento de $200 \% \mathrm{em}$ 2013 em relação a 2010, destacam-se o Decreto n⒎746/2012 que estabelece critérios e diretrizes para a promoção do desenvolvimento nacional sustentável nas contratações públicas; a inclusão de informações sobre sustentabilidade de produtos no Catálogo de Materiais (CATMAT); Acordo de Cooperação Técnica para criação do Fórum Permanente de diálogo entre os setores público e privado para promover o debate sobre o tema de produção e consumo sustentáveis; repasse de recursos para mais de 4.500 escolas públicas da educação básica por meio do Programa Dinheiro Direto na Escola (PPDE) Escolas Sustentáveis, do MEC; opção de compras de coletores solares ao invés do uso de chuveiros elétricos no Programa Minha Casa Minha Vida; além de várias outras medidas e ações como a realização de compras públicas compartilhadas sustentáveis. 
No âmbito da Agenda Ambiental na Administração Pública foi duplicado o número de parceiros no período entre 2011 e 2014, contando atualmente com a adesão de 159 instituições municipais, 168 estaduais e 168 federais. Destacam-se aqui, as campanhas de sensibilização que coletaram 4,1 toneladas de material eletroeletrônico; três edições do Fórum Nacional da A3P somando cerca de 1.200 participantes, além de quatro fóruns regionais que contaram com aproximadamente 410 participantes; três edições do Prêmio A3P de Melhores Práticas de Sustentabilidade, as quais envolveram perto de 1.200 pessoas; e o lançamento do Selo de Sustentabilidade na Administração Pública (Selo A3P), o qual já certificou 112 instituições com o Selo Verde (adesão formal), 8 com o Selo Prata (entrega de relatório anual) e 10 com o Selo Laranja (vencedores do Prêmio A3P).

No âmbito do aumento de reciclagem de resíduos sólidos destacam-se o investimento de mais de $\mathrm{R} \$ 1,2$ bilhão no fomento à elaboração de planos de resíduos sólidos; o Programa Cataforte - Negócios Sustentáveis em Redes Solidárias o qual prevê contar com 170 milhões de recursos não reembolsáveis e mais 30 milhões de recursos reembolsáveis; Prêmio Cidade Pró-Catador, que visa incentivar, valorizar e dar visibilidade a práticas que contribuam para a implementação de políticas de inclusão social e econômica de catadores de material reciclável, em especial na implantação da coleta seletiva; e a criação de associações empresariais, como a Coalizão Empresarial para a Logística Reversa de Embalagens, que definiu como meta recuperar 20\% das 55,4 mil toneladas de resíduos sólidos recicláveis que são descartadas diariamente no Brasil.

No âmbito do varejo sustentável, o qual representa 14\% do PIB do Brasil, desde a implementação do PPCS, o setor incrementou suas iniciativas de práticas voltadas para a redução no uso de recursos e na geração de resíduos; foram ampliadas o número de lojas ecoeficientes; o número de pontos de entrega voluntária de embalagens e resíduos aumentou; aumentou a oferta de produtos sustentáveis; incentivo a produtos que apresentam selos de qualidade e que incluam critérios socioambientais em seus processos de certificação.

No âmbito das construções sustentáveis destacam-se o Programa Brasileiro de Qualidade e Produtividade do Habitat (PBQP-H), o qual desenvolveu, em parceria com o setor público e privado, sistemas matriciais avaliativos; financiamento extra para instalação de aquecimento solar de água nas casas populares do Programa Minha Casa Minha Vida que proporcionam uma economia média de 35\% no consumo de energia elétrica; Selo Casa Azul da Caixa Econômica Federal, que visa promover a sustentabilidade no setor da construção por meio da classificação socioambiental dos projetos habitacionais financiados pela CAIXA; além de outras iniciativas como a 
certificação e gestão sustentável de arenas esportivas, particularmente aqueles realizados em função da realização da Copa do Mundo 2014, que se tornaram exemplo não apenas para o Brasil, mas para todo o mundo.

\subsection{O AUMENTO DA RENDA DA POPULAÇÃO ATRAVÉS DE PROGRAMAS DE TRANSFERÊNCIA DE RENDA}

Como citado na seção anterior, o governo utiliza suas políticas públicas para viabilizar a construção de um mercado de consumo de massa com a finalidade de obter crescimento econômico em seu processo de desenvolvimento.

O Programa Bolsa Família é um instrumento utilizado pelo governo para enfrentar a vulnerabilidade social e elevar a condição financeira da população. É um programa federal de transferência de renda, instituído por lei em 2004, destinado às famílias em situação de pobreza e extrema pobreza que associa à transferência do benefício financeiro do acesso aos direitos sociais básicos - saúde, alimentação, educação e assistência social. Ao longo dos anos o número de famílias beneficiadas pelo programa vem aumentando. Conforme o gráfico abaixo é possível visualizar a quantidade de famílias que receberam o benefício desde a implementação do programa.

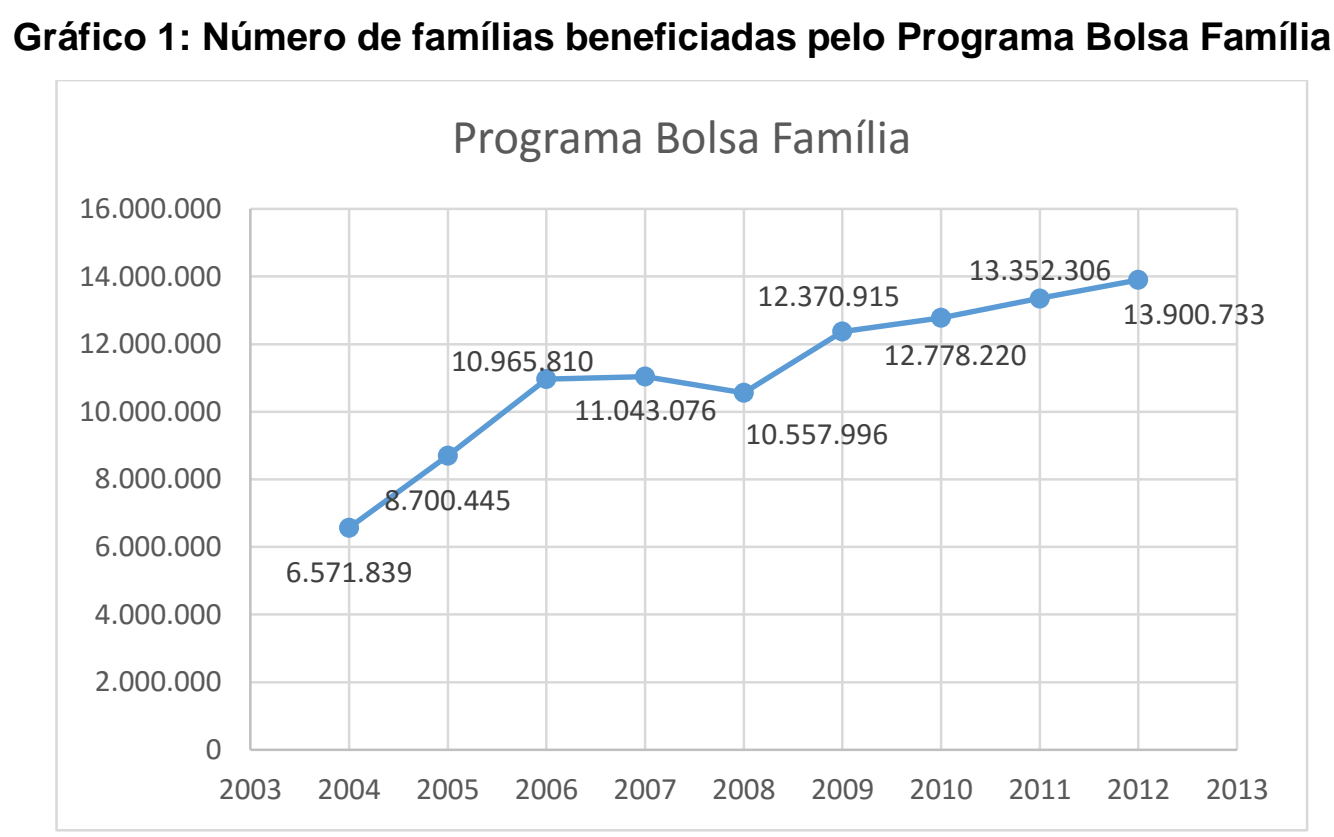

Fonte: Elaboração própria com base nos dados do IPEA data.

Ao longo do período com dados disponíveis foi possível perceber que o número de famílias beneficiárias do programa mais que dobrou passando de 6.571 .839 em 2004 para 13.900 .733 no ano de 2012. 
Já o programa habitacional Minha Casa, Minha Vida, foi elaborado para viabilizar a construção de unidades habitacionais para a população de baixa renda. O programa que tem o objetivo de compatibilizar a prestação da casa própria com a capacidade de pagamento das famílias, surgiu em 2009, e desde então já atingiu 3,857 milhões de moradias, sendo que desse total, as famílias já beneficiadas receberam 2,169 milhões de moradias enquanto 1,688 milhão de casas e apartamentos já foram contratados para entrega nos próximos meses e anos.

O surgimento do programa é considerado um dos mais importantes projetos do PAC na busca por desenvolvimento e crescimento econômico. Ao mesmo tempo, a expansão da infraestrutura do país pode representar uma ameaça ao meio ambiente, à saúde da população e às relações sociais. Projetos de infraestrutura podem estimular o desenvolvimento sustentável desde que planejados dentro do contexto específico de cada bioma, levando em conta as potencialidades e fragilidades de cada território, assim como as especificidades das comunidades locais.

Para avaliar os impactos da infraestrutura no meio ambiente, a legislação ambiental brasileira instituiu a obrigatoriedade de estudos de impacto ambiental para empreendimentos que podem causar danos ao meio ambiente através da Lei nำ 6.938 de 1981 e Resoluções 001/86 e 237/98 do Conselho Nacional de Meio Ambiente.

Para Renato Rosenberg (2016), o PAC auxilia o país a se desenvolver conciliando desenvolvimento e meio ambiente, pois quando as infraestruturas são criadas, elas agregam valor e trazem a possibilidade de obtenção de recursos para preservar melhor o meio ambiente. Segundo o entrevistado lan Ramalho (2016), todos os projetos precisam ter licenciamento ambiental e um acompanhamento para que os empreendimentos atendam às exigências ambientais.

Segundo a entrevistada Raquel Breda (2016), a cada edição do Programa Minha Casa, Minha Vida, há um aumento dos requerimentos ambientais que favorecem as questões sociais, melhorando os entornos, implementando captação de água, energia solar etc. Para o entrevistado Renato Rosenberg (2016), a inclusão de variáveis ambientais na área da infraestrutura é uma opção para o planejamento nacional para o alcance do desenvolvimento sustentável.

Conforme o país aumenta sua capacidade de se desenvolver, criando maiores oportunidades para a população, assim como condições reais de melhoria de vida, o consumo das pessoas apresenta uma mudança de perfil significativo. Essa mudança de perfil faz com que o estilo de vida das pessoas seja influenciado por tudo aquilo que está em sua volta. Neste sentido, a população, ao ter condições de se manter em um emprego decente e desde que tenha acesso a serviços essenciais para o seu bem-estar 
sente-se empoderada a consumir de maneira desenfreada, o que pode vir a acarretar em crises financeiras e ambientais.

Segundo Alves (2011), o crescimento do emprego e da renda no Brasil, conjugado com a redução do desemprego e das desigualdades sociais, permite a formação de um mercado de consumo de massas e do crescimento do poder de compra de parcelas cada vez maior da população brasileira.

A questão da inserção produtiva, de se enfrentar o desemprego e a falta de trabalho para um grande número de pessoas precisaria ser equacionada de maneira coerente, segundo Morais e Costa (2010), com a necessidade de construção de novos paradigmas de produção e consumo, especialmente considerando os desafios da degradação ambiental.

Frente à perda de empregos, alguns países têm adotado medidas de estímulo econômico com investimentos em setores "verdes", como energia eólica, solar, térmica, biomassa, hidroelétrica, geotérmica. Essas medidas, de acordo com Morais e Costa (2010), além de contribuírem para a transformação da matriz energética atual, geram empregos, incluem os menos favorecidos e melhoram a eficiência energética de edifícios, no transporte público, nos aparelhos elétricos e nos automóveis, bem como ampliam a diversificação de energia limpa e renovável.

Souza e Lamounier (2010) afirmam que o crescimento econômico do Brasil nos últimos anos, traduziu-se na percepção de um nível maior de renda permanente, expandindo a demanda dos consumidores. Para os autores, o acesso ao crédito possibilitou o consumo de bens até então inacessíveis às classes mais baixas, erodindo seu valor simbólico para a definição de uma identidade de classe média. O consumo a partir disso, volta-se para bens conspícuos, denotadores de prestígio, diferentemente de antigamente quando a prioridade era o aumento do ativo e da poupança.

Para Souza e Lamounier (2010), os gastos discricionários (educação, saúde, higiene, cuidados pessoas) sobem de maneira acentuada, enquanto os gastos com necessidades básicas (alimentação, vestuário, transporte, habitação) tendem a se estabilizar em níveis relativamente baixos na distribuição da despesa familiar.

Segundo o gráfico abaixo, extraído da Avaliação do PPA 2008-2011, é possível perceber que o consumo das famílias representa uma parte significativa do PIB, sendo, portanto, essencial para a expansão da economia.

Porém, as características utilizadas como base para o cálculo do PIB somente levam em conta indicadores econômicos. Segundo Morais e Costa (2010), o PIB se mostra uma medida insuficiente para mensurar a qualidade de vida de uma população, pois se o objetivo principal do desenvolvimento passar a ser a melhoria da qualidade de 
vida da população, não faria sentido qualquer crescimento econômico que não trouxesse a redução da pobreza e inclusão social.

\section{Gráfico 2: Evolução do Consumo das Famílias}

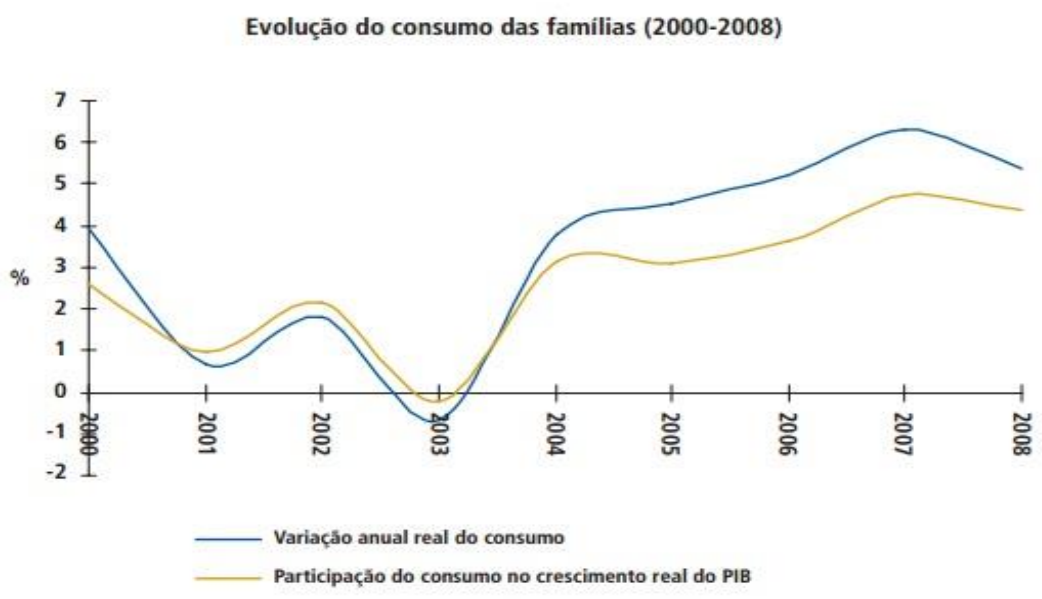

Fonte: Contas Nacionais/IBGE - Elaboração: SPI/MP

Com a ascensão do consumo nas classes C, D e E devido a fatores como o aumento do salário mínimo, programas de transferências de renda, entre outros, percebe-se uma alteração no perfil da classe média brasileira. Segundo a Pesquisa de Orçamentos Familiares do IBGE, as despesas de consumo das famílias passaram de $R \$ 17.583,72$ por ano em 2003 para $R$ \$ 25.617,24 em 2009. Essas despesas incluem gastos com habitação, alimentação, educação, saúde, transporte, entre outras, conforme pode ser visto no gráfico abaixo (GUIMARÃES, 2011). 


\section{Gráfico 3: Consumo Mensal Familiar (período 2008-2009)}

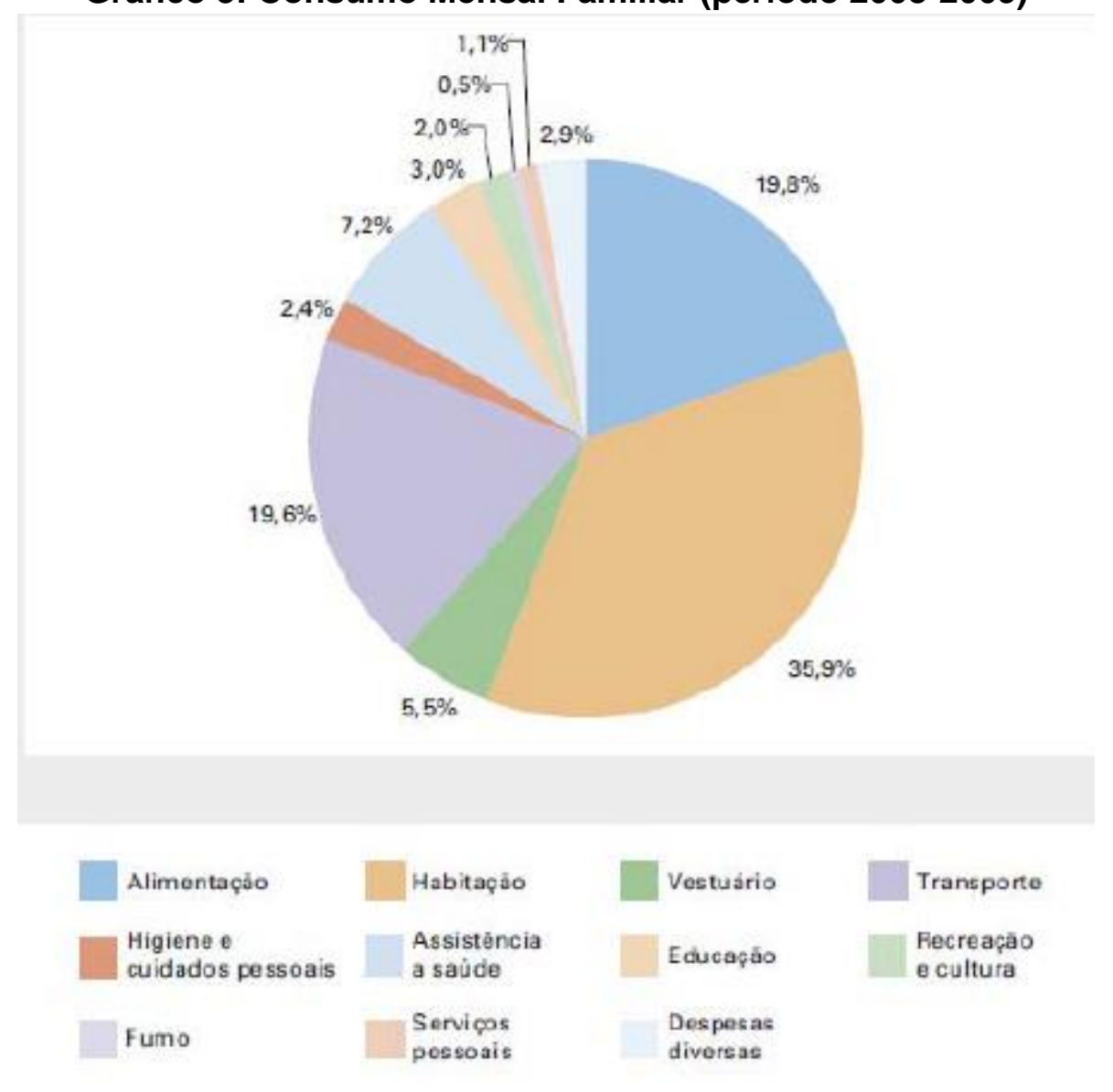

Fonte: IBGE, 2009.

Apesar de o consumo ser um dado importante para a análise do desempenho econômico de um país, esse dado deve ser utilizado com certo cuidado, pois impacta diretamente o meio ambiente na relação entre oferta e demanda.

É através da mudança no estilo de vida das pessoas, afetando seu consumo que é possível afetar toda a cadeia de produção, pois é a demanda que vai decidir como essa oferta tem que vir. Se a demanda for qualificada com produtos de menor impacto ambiental, de menor utilização de recursos, com um consumo mais racional e responsável, isso se reflete em todas as cadeias (BREDA, 2016 - entrevista).

Por isso, ao mesmo tempo em que há uma política de ampliação de mercado interno para dar dinamismo à economia brasileira, há uma preocupação política e moral com diversos valores, dentre eles, a sustentabilidade. Existem regras e normatizações que impedem o consumo de bens que possam vir a ser poluidores e ao mesmo tempo há campanhas políticas para que a população incorpore em seu conjunto de opções de consumo, produtos que não agridem o meio ambiente. Aquele produto que faz além do 
que é obrigatório, começa a ter vantagens no mercado a medida em que a população acredite na sua importância para o meio ambiente (RAMALHO, 2016 - entrevista).

\subsection{RECURSOS NATURAIS}

A partir do momento em que a questão do consumo é escolhida como um dos 17 objetivos de desenvolvimento sustentável do âmbito da agenda 2030 das Nações Unidas, percebe-se uma inter-relação, pois essa condição afeta e é afetada por todos os outros objetivos. Não é possível pensar em energia sem pensar no uso eficiente de recursos e na diversificação das matrizes, por exemplo.

O emprego de fontes não renováveis, como o petróleo e o gás natural podem acarretar em maiores riscos ambientais. E o consumo de petróleo e de gás natural no Brasil tem aumentado significativamente no decorrer do tempo, conforme a tabela a seguir.

Tabela 1: Consumo de petróleo e gás natural no Brasil

\begin{tabular}{|c|c|c|c|c|c|c|c|c|c|c|c|}
\hline & $\mathbf{2 0 0 3}$ & $\mathbf{2 0 0 4}$ & $\mathbf{2 0 0 5}$ & $\mathbf{2 0 0 6}$ & $\mathbf{2 0 0 7}$ & $\mathbf{2 0 0 8}$ & $\mathbf{2 0 0 9}$ & $\mathbf{2 0 1 0}$ & $\mathbf{2 0 1 1}$ & $\mathbf{2 0 1 2}$ & $\mathbf{2 0 1 3}$ \\
\hline $\begin{array}{c}\text { Petróleo } \\
\text { (mil } \\
\text { barris/dia) }\end{array}$ & 1.973 & 2.050 & 2.097 & 2.134 & 2.286 & 2.439 & 2.467 & 2.669 & 2.730 & 2.807 & 2.973 \\
\hline $\begin{array}{c}\text { Gás } \\
\text { Natural } \\
\text { (bilhões } \\
\text { m3) }\end{array}$ & 15,8 & 18,8 & 19,6 & 20,6 & 21,2 & 24,9 & 20,1 & 26,8 & 26,7 & 31,7 & 37,6 \\
\hline
\end{tabular}

Fonte: Elaboração própria com base nos dados da Agência Nacional do Petróleo, Gás Natural e Biocombustíveis.

Para enfrentar o aumento da demanda do futuro sob a ótica do consumo sustentável, seria necessário eliminar os desperdícios e buscar fontes alternativas mais eficientes e seguras, como por exemplo, a produção e energia a partir de fontes perenes, como o Sol e o vento.

A energia eólica vem gerando grande interesse nos últimos anos, mostrando-se uma das fontes de energia que mais crescem. A produção de energia eólica no Brasil vem se expandindo cada vez mais ao longo dos anos. Em 2002, o governo lançou o Programa de Incentivo às Fontes Alternativas de Energia Elétrica para ampliar as matrizes que geram menos impactos ambientais, dentre elas a eólica, a solar, a geotérmica e outras. 
Em matéria publica no Portal Brasil², em 30 de julho de 2015, o Brasil bateu recorde de produção de energia eólica produzindo em apenas um dia 2.982,2 megawatts médios de energia gerada pela força dos ventos, o que seria suficiente para abastecer 13 milhões de pessoas. A estimativa do governo é que até 2023 a utilização de fontes de energia renováveis na matriz energética possa chegar até $84 \%$.

O gráfico abaixo apresenta a evolução da capacidade instalada da fonte eólica e a previsão de crescimento em função das contratações já realizadas nos leilões regulados e no mercado livre.

\section{Gráfico 4: Evolução da capacidade de energia eólica}

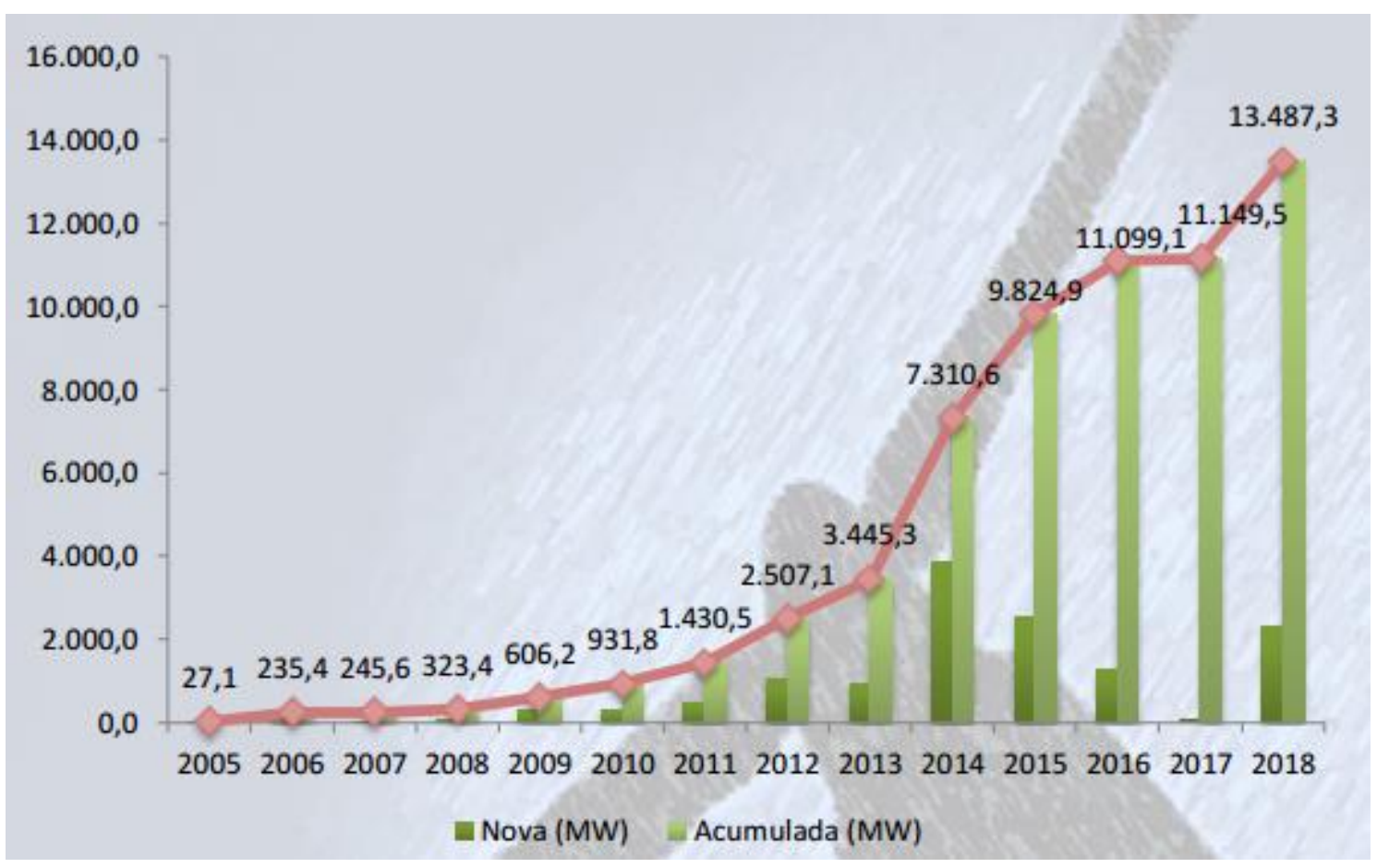

Fonte: Aneel/ABEEólica

O mundo vive hoje o que alguns especialistas chamam de radical greening, um aumento das preocupações ambientais entre os consumidores e os governos. Segundo Voltolini (2009), muitos setores como o petróleo e gás, seguros, energia, saneamento e automotivo têm visualizado isso como uma ameaça a seus negócios e já começam a trabalhar com um cenário futuro de forte pressão exercida sobre suas atividades. Empresas mais inteligentes já compreenderam que não devem desconsiderar a sustentabilidade em suas estratégias de gestão e relacionamento com os consumidores.

\footnotetext{
${ }^{2}$ Disponível em: <http://www.brasil.gov.br/infraestrutura/2015/07/brasil-bate-recorde-na-producao-deenergia-eolica>
} 
Outra questão preocupante é a biodiversidade da floresta, sendo necessárias várias medidas de conservação. De imediato seria necessário sustar o desflorestamento. Na medida em que se afirmar a viabilidade do aproveitamento econômico da biodiversidade, há que se valorizar a floresta em pé para que possa competir com as commodities. Para isso, necessita-se fortalecer o sistema de classificação, detalhamento, monitoramento e fiscalização do desmatamento e uso de terra. A construção de cadeias produtivas e produtos não madeireiros associados ao fortalecimento das comunidades locais é igualmente urgente, apoiada pelo aprimoramento genético de espécies, bem como de sistemas de produção e geração de indicadores ambientais de manejo florestal e uso múltiplo para o bioma amazônico (MCTI, 2010).

Segundo o entrevistado Fábio Larotonda (2016), o governo vem tentando com a ENCTI propor ações que minimizem a degradação dos recursos naturais, para isso discute a utilização da floresta em pé, ao qual seus recursos são extraídos sem a necessidade de derrubada. Para a entrevistada Raquel Breda (2016), não é necessário abrir novas áreas para a produção agrícola, pois já existe uma grande quantidade de áreas abertas passiveis de recuperação. Com as obrigações trazidas pelo $\mathrm{CAR}^{3}$ é possível que haja um aumento de áreas, pois uma das obrigações é a recuperação de áreas para aumento das taxas de cobertura florestal.

\subsection{PROGRAMAS EDUCACIONAIS}

Segundo Roth e Garcias (2008), é fundamental adotar uma educação ambiental como política para sensibilizar e conscientizar a sociedade para agir de maneira mais pensada com relação aso resíduos sólidos e aos padrões ideias de consumo. A educação ambiental serviria para alertar e informar, estabelecendo uma consciência mais crítica com relação aos problemas ambientais.

De acordo com Pereira e Calgaro (2012), a educação para o consumo sustentável pode trazer modificações na forma como o consumidor se comporta perante a compra, a utilização e o descarte de bens, criando uma consciência na aquisição do estritamente necessário para a sua sobrevivência. Para os autores, essa educação pode transformar inclusive o comportamento dos produtores, fabricantes e fornecedores em geral a partir da conscientização sobre a utilização de insumos não agressivos ao meio ambiente, a criação de políticas de limpeza de rejeitos industriais antes de colocá-los em contato

\footnotetext{
${ }^{3}$ O CAR (Cadastro Ambiental Rural) é o registro público eletrônico de âmbito nacional, obrigatório para todos os imóveis rurais, com a finalidade de integrar as informações ambientais das propriedades e posses rurais, compondo base de dados para controle, monitoramento, planejamento ambiental e econômico e combate ao desmatamento.
} 
com a natureza, a criação de mecanismos de recolhimento das embalagens nocivas ao meio ambiente, entre outras.

O desafio proposto para a educação ambiental é compor uma concepção crítica que aponte para a descoberta conjunta de como promover a qualidade de vida ao mesmo tempo em que se preserve os recursos naturais. Essa concepção propõe a formulação de novos valores na construção de sociedades sustentáveis, que ultrapassam o campo único da economia e passam a envolver a sustentabilidade social, ambiental, política e ética (SEQUINEL; CARON, 2010).

O Brasil lançou em 1996, o Programa Nacional de Educação Ambiental (ProNEA) para assegurar a integração equilibrada das múltiplas dimensões da sustentabilidade ao desenvolvimento do País, resultando em melhor qualidade de vida para toda a população brasileira, por intermédio do envolvimento e participação social na proteção e conservação ambiental e da manutenção dessas condições ao longo prazo.

O ProNEA desempenha o papel de orientar os agentes públicos e privados a refletir e construir alternativas que almejem a sustentabilidade. A participação e o controle social são diretrizes que permeiam suas estratégias e ações por meio da geração e disponibilização de informações que permitam a participação social na discussão, formulação, implementação, fiscalização e avaliação das políticas ambientais voltadas à construção de valores culturais comprometidos com a qualidade ambiental e a justiça social; e de apoio à sociedade na busca de um modelo socioeconômico sustentável.

Além disso, mais recentemente, o governo brasileiro lançou em 2005, o Manual de Educação para Consumo Sustentável para promover a conscientização social quanto o consumo sustentável. O livro já foi utilizado pelo Ministério de Educação e Cultura para servir de base a trabalhos desenvolvidos em escolas de 4.400 municípios brasileiros. A publicação oferece informações sobre uso correto de água, produção de alimentos orgânicos e seus benefícios para a comunidade, preservação da biodiversidade, influências do transporte nas mudanças climáticas, economia de energia e dicas de reutilização e reciclagem de lixo.

Segundo o Manual de Educação para Consumo Sustentável do governo brasileiro, mesmo os países como o Brasil, que possuem recursos hídricos abundantes, não estão longe da ameaça de crise de água. As reservas de água potável estão diminuindo cada vez mais e as principais causas são o crescente aumento do consumo, o desperdício e a poluição das águas superficiais e subterrâneas por esgotos domésticos e resíduos tóxicos provenientes da indústria e da agricultura.

Os benefícios proporcionados pelo desenvolvimento tecnológico, segundo o Manual de Educação para Consumo Sustentável, é o crescimento constante do 
consumo de energia. Para isso, os governos precisam investir cada vez mais na construção de usinas de geração e de linhas de transmissão e distribuição. Porém, esse investimento levaria a uma série de prejuízos ao meio ambiente, onde a gravidade dos impactos ambientais depende da fonte de energia usada na geração de eletricidade.

Em 2013, o governo lançou a Cartilha "Construções e Reformas Particulares Sustentáveis" que traz orientações sobre como fazer moradias sustentáveis que gerem economia e durabilidade. O objetivo é difundir práticas de obras sustentáveis aos consumidores, permitindo a otimização dos recursos financeiros e naturais investidos. As dicas da publicação para tornar a obra sustentável vão desde o projeto até o descarte dos resíduos sólidos. De acordo com os dados da cartilha, uma casa ou prédio sustentável gera uma economia de aproximadamente $30 \%$ em sua manutenção, gasta menos água e energia elétrica e tem uma vida útil muito maior. O uso de material reciclado em lugar de produtos novos também poderá trazer economia.

\subsection{GERAÇÃO DE RESÍDUOS}

Visto que o consumo apresenta cada vez mais um aumento acelerado devido às condições do sistema vigente, políticas de geração de resíduos, assim como de saneamento e acesso à moradia podem trazer condições a longo prazo para as futuras gerações, marco do conceito de desenvolvimento sustentável.

Roth e Garcias (2008) citam D'Almeida e Villhena (2000) para exemplificar o que seriam os resíduos sólidos urbanos. Estes, podem ser caracterizados como o conjunto de detritos gerados em decorrência das atividades humanas nos aglomerados urbanos, incluindo os resíduos domiciliares, os originados nos estabelecimentos comerciais, industriais e de prestação de serviços, os decorrentes dos serviços de limpeza pública urbana, os oriundos de estabelecimento de saúde, os entulhos da construção civil e os gerados em terminais rodoviários, ferroviários, portos e aeroportos.

A inadequada coleta e destinação final dos resíduos provocados pelo crescimento das cidades, aliado às mudanças econômicas, de tecnologia e de consumo, acarreta danos ambientais como a contaminação do solo, a poluição das águas superficiais e subterrâneas, geração de focos de proliferação de doenças, obstrução dos sistemas de drenagem, ocasionando enchentes e inundações, prejudicando o sistema urbano (ROTH; GARCIA, 2008).

A geração de resíduos traz diversos problemas para a sociedade e para o planeta. Dentre alguns desses problemas destaca-se o depósito a céu aberto que pode ocasionar poluição do solo, ar água e visual; o esgotamento de fontes de matéria-prima; dificuldade de obtenção de água apropriada ao uso; dificuldade de encontrar áreas para 
implantação de aterros sanitários; escassez e custo crescente de energia, entre outros (ROTH; GARCIA, 2008).

Segundo Roth e Garcias (2008) o governo deve implementar programas que visem à redução de resíduos, sensibilizando a população desde a aquisição de produtos até o seu descarte para buscar manter um crescimento sustentável com garantia de qualidade de vida para as futuras gerações.

Um sistema de esgoto eficiente, por exemplo, pode afastar a possibilidade de contato de dejetos humanos com a população, com as águas de abastecimento, com vetores de doenças e alimentos. Os investimentos em saneamento, porém, deveriam atender a requisitos técnicos, ambientais, sociais e econômicos paralelamente ao conceito de desenvolvimento sustentável, de preservação e conservação do meio ambiente. A eficiência desse tipo de sistema diminui o número de doenças, mortes e pode contribuir para a diminuição da pobreza. O gráfico abaixo apresenta a porcentagem de pessoas que vivem em domicílios particulares com acesso a instalações de esgoto no Brasil, ou seja que tem banheiro de uso exclusivo e com escoadouro conectado à rede coletora de esgoto ou pluvial ou a uma fossa séptica ligada ou não a uma rede coletor.

\section{Gráfico 5: Pessoas com acesso a instalações de esgoto em domicílios particulares (Valores em porcentagem)}

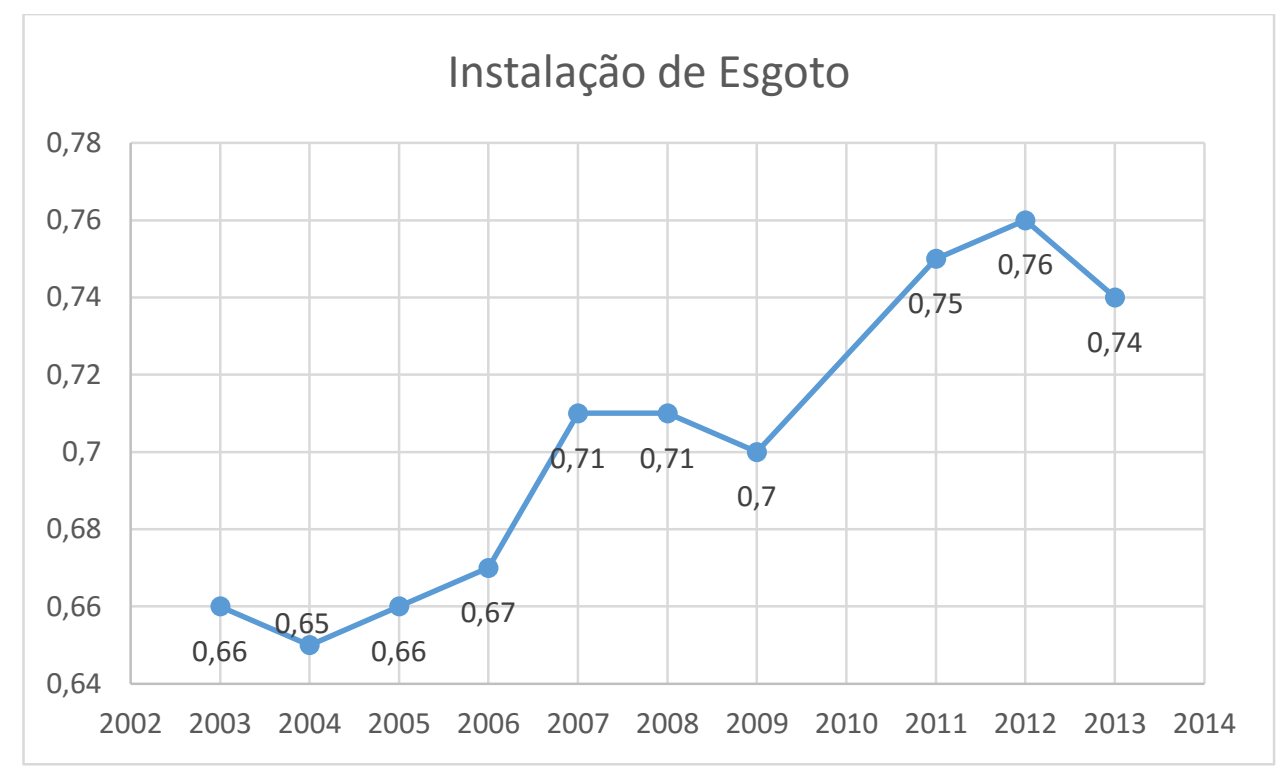

Fonte: Elaboração própria com base nos dados do IPEA data.

Além da instalação adequada de esgoto, há a necessidade de um sistema de coleta seletiva adequado para compensar a quantidade de resíduos produzidos pela 
população. A coleta seletiva é uma alternativa que induz ao desenvolvimento da atividade de reciclagem de resíduos, buscando minimizar os impactos ambientais.

O governo brasileiro instituiu em 2010, a Política Nacional de Resíduos Sólidos (PNRS) para enfrentar os principais problemas ambientais, sociais e econômicos decorrentes do manejo inadequado dos resíduos sólidos. Desde sua implementação, a PNRS mais que dobrou o número de municípios com algum tipo de coleta seletiva. $\mathrm{A}$ PNRS prevê a prevenção e a redução na geração de resíduos propondo hábitos de consumo sustentável e um conjunto de instrumentos para propiciar o aumento da reciclagem e da reutilização dos resíduos sólidos, além da destinação ambientalmente adequada dos rejeitos. O gráfico abaixo apresenta a quantidade de cidades com coleta seletiva no Brasil desde o ano de 2002.

\section{Gráfico 6: Cidades com coleta seletiva no Brasil}

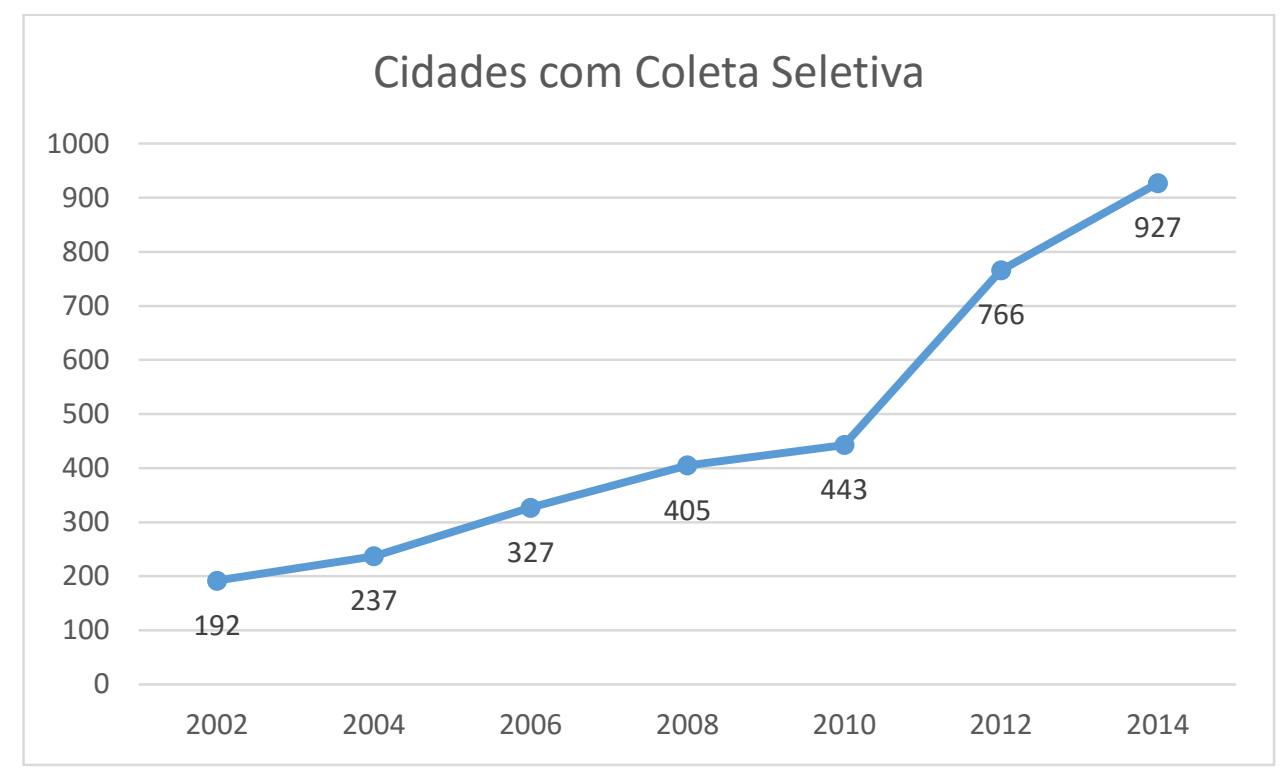

Fonte: Elaboração própria com base nos dados da Pesquisa Ciclosoft da CEMPRE.

O aparecimento da coleta seletiva em várias cidades do país, assim como uma maior preocupação com as instalações de esgoto em cada região demonstra o anseio do governo em tentar satisfazer as necessidades básicas da população, oriundas do impacto causado pelo aumento da população economicamente ativa e maiores índices de salário mínimo, sem deixar de lado a questão ambiental. É a partir desse ponto que o social e o ambiental andam lado a lado, pois são as políticas públicas voltadas a elevar a condição financeira da população que traçam uma mudança no perfil do consumo das famílias que passam a ter acesso a determinados bens e serviços que não estavam ao seu alcance. O aumento da demanda por serviços e bens superficiais vem acompanhado de uma série de atividades, como o desperdício, a poluição e o descarte 
incorreto de resíduos que se apresentam como resultado desse consumo, sendo necessário o surgimento de novas tecnologias para inovar a maneira do país em manter sua própria sustentabilidade. 


\section{CONSIDERAÇÕES FINAIS}

O aumento do consumo, nos dias de hoje, é considerado um requisito essencial para a manutenção do sistema econômico capitalista. Grande parte da sustentação desse sistema depende do consumo como parte inerente de seu crescimento econômico. Com maiores índices de desenvolvimento humano, mais bens e serviços são produzidos e consumidos, porém, mais recursos renováveis e não renováveis são utilizados para alimentar esse crescimento, trazendo perdas ao meio ambiente. É necessário que a variável ambiental esteja presente nas discussões acerca do crescimento econômico, pois não se pode pensar apenas em aumento do consumo sem pensar no que está por trás dessa condição. Atualmente, há um crescimento constante de preocupação por parte das pessoas com relação à sustentabilidade. A procura por bens e serviços que trazem a condição ambiental em seus princípios e valores tem ganhado fôlego fazendo com que tanto o governo como as empresas passem a incorporar cada vez mais a preservação do meio ambiente em suas ações e políticas.

Tendo em vista os aspectos mencionados no decorrer dessa dissertação, foi possível perceber que ao longo dos últimos anos o Brasil tem estimulado o consumo através de programas de transferência de renda e da facilitação do acesso ao crédito para a população. Em seus Planos Plurianuais, o governo busca a igualdade social com educação de qualidade, produção de conhecimento, inovação tecnológica e a sustentabilidade ambiental tomando como base o fortalecimento do mercado interno com a redução das desigualdades.

Neste sentido, o país vem atuando fortemente para consolidar um padrão de transformações estruturais, principalmente no seu eixo social. Foram criados diversos programas para proporcionar a inclusão das famílias nos circuitos de produção e consumo para obter ganhos de escala que contribuiriam para o aumento da produtividade. Dentre os programas, destaca-se o Programa de Aceleração do Crescimento, Plano de Desenvolvimento da Educação, Programa Minha Casa, Minha Vida, Brasil Sem Miséria, Pronatec e o Programa Ciências Sem Fronteiras.

Na sua dimensão ambiental, o governo vem se comprometendo a compatibilizar a capacidade de distribuir os benefícios de modo mais equitativo com o compromisso de abandonar práticas que causem danos ao meio ambiente, estabelecendo relações equilibradas, benéficas e permanentes entre a sociedade a natureza. Parece que a estratégia brasileira busca consolidar a visão de que o desenvolvimento já não está mais associado ao crescimento econômico, tendo como parâmetro principal a redução das desigualdades com sustentabilidade. 
Através da Estratégia Nacional de Ciência, Tecnologia e Inovação o governo tenta contornar sua defasagem em ciência e tecnologia, buscando um crescimento com redistribuição de renda, incorporando um grande contingente populacional ao mercado de consumo de massa, tentando não deixar de lado a preservação dos aspectos essenciais da sustentabilidade.

Com o Plano de Ação para Produção e Consumo Sustentáveis o governo vem pretendendo guiar suas ações no que se refere a educação para o desenvolvimento sustentável, compras públicas sustentáveis, agenda ambiental para a administração pública, reciclagem de resíduos sólidos, varejo sustentável e construção sustentável. Conforme exposto na dissertação, o Brasil conseguiu dar alguns passos em caminho ao desenvolvimento sustentável com esses planos. O primeiro ciclo de implementação do PPCS trouxe importantes resultados na sua busca por políticas que visam a conservação dos recursos naturais existentes com a realização de grandes conferências, programas, projetos, decretos etc. Apesar de sua primeira avaliação ter sido positiva, ainda há muito que ser feito com relação ao PPCS, que segundo os entrevistados, pode ser considerado um dos principais carros-chefes do governo no sentindo da sustentabilidade. Durante as entrevistas, foi possível perceber que o plano agrada na forma como está estruturado, mas que possui uma grande debilidade: a falta de indicadores de monitoramento. O monitoramento e a avaliação se tornam essenciais em qualquer política pública, principalmente no que tange a ações e projetos referentes ao meio ambiente. Segundo a entrevista Raquel Breda, os indicadores de monitoramento já estão sendo elaborados para que no próximo ciclo possam ser utilizados para assim, apresentarem resultados mais concretos.

As indagações que surgiram no processo de elaboração desta dissertação trouxeram a necessidade de buscar entender de que forma as ações governamentais afetam o sistema produtivo e como o governo tenta compatibilizar as demandas econômicas, sociais e ambientais considerando suas políticas públicas a partir do consumo.

O Programa Bolsa Família, ao transferir renda para a população, e o Programa Minha Casa, Minha Vida, ao viabilizar a construção de unidades habitacionais para as pessoas, elevaram a condição financeira da população e possibilitaram um acesso mais fácil a atividade do consumo. Junto com esse acesso ao consumo, vem uma mudança no comportamento consumista das pessoas que passam a adquirir bens e serviços que antes não teriam acesso.

Dessa forma, seria impossível tratar a questão do consumo sem levar em conta as políticas públicas governamentais, pois quanto maior o poder de compra da população, maior é a necessidade de novos produtos, maior é a expectativa pelo 
atendimento das necessidades básicas e maior é a necessidade de programas e ações que visem controlar os percalços decorrentes dessa situação no que tange aos seus impactos gerados no meio ambiente.

Essa evolução no consumo da população traz consequências positivas para o PIB, mas ao mesmo tempo apresenta condições insustentáveis para o meio ambiente. Para suprir a necessidade dessa população e das futuras gerações, políticas públicas de saneamento e de coleta seletiva se tornam chave para a aproximação do conceito de desenvolvimento sustentável. Um sistema de esgoto eficiente reduz o risco de doenças e a coleta seletiva proporciona uma destinação adequada de resíduos para evitar que a população obtenha qualquer tipo de contaminação.

Além disso, a questão da energia se torna de extrema importância para a ótica do consumo sustentável, sendo necessária a utilização de formas alternativas de energia, como a energia eólica, a qual o Brasil vem desenvolvendo ao longo dos anos, em substituição a fontes não renováveis, como o petróleo e o gás.

Considerando isto, percebe-se que o desenvolvimento do Brasil é condicionado pela prática do consumo, pois sua variação determina em que estágio o país se encontra, demonstrando caminhos para a criação de políticas que visem melhorar o bem-estar da população e a conservação do meio ambiente. Por todos esses aspectos, entende-se que o consumo impacta diretamente no meio ambiente, pois é dele que sai tudo aquilo que consumimos e, portanto, deve-se buscar meios alternativos de preserválo ao máximo para não enfrentarmos problema futuramente.

Apesar de o governo apresentar diversos planos referentes aos problemas derivados dos impactos ambientais, muito ainda precisa ser feito e analisado. Os entrevistados afirmaram que há uma articulação entre os ministérios e órgãos sempre que um projeto ou ação é elaborado, a exemplo disso, o PAC busca ter licenciamento ambiental em todos os projetos e o Programa Minha Casa, Minha Vida, apresenta requerimentos ambientais para as construções. A preocupação com o meio ambiente está cada vez mais presente nas discussões decorrentes do desenvolvimento e não devem ser esquecidas. Antes de estimular um consumo desenfreado, o governo deveria procurar formas de equilibrar esse consumo, por exemplo, utilizando a floresta em pé para minimizar a degradação dos recursos naturais.

Essa dissertação apresentou algumas limitações para sua realização. Mais categorias podem ser apresentadas em estudos futuros e uma abordagem mais ampla em cada uma das categorias poderia apresentar melhores resultados.

Apesar das limitações identificadas e de outras que podem ser apontadas, considera-se que o presente trabalho permitiu trazer a visão de que o consumo deve 
estar na pauta das discussões referentes ao desenvolvimento e que seus impactos podem ser visivelmente prejudiciais ao meio ambiente.

Por fim, acredita-se que a integração de interesses sociais e econômicos com as possibilidades e os limites que a natureza define é caminho a ser percorrido para o alcance de um desenvolvimento que seja sustentável e para isso as políticas públicas devem estabelecer uma maior conexão entre o meio ambiente e o desenvolvimento de forma que o consumo esteja pautado na estratégia de desenvolvimento sustentável brasileira. 


\section{REFERÊNCIAS BIBLIOGRÁFICAS}

AGÊNCIA NACIONAL DO PETRÓLEO, GÁS NATURAL E BIOCOMBUSTÍVEIS. Anuário estatístico brasileiro do petróleo, gás natural e biocombustíveis: 2014 / Agência Nacional do Petróleo, Gás Natural e Biocombustíveis. -Rio de Janeiro : ANP, 2008.

AGÊNCIA NACIONAL DO PETRÓLEO, GÁS NATURAL E BIOCOMBUSTÍVEIS. Anuário estatístico brasileiro do petróleo, gás natural e biocombustíveis: 2013 / Agência Nacional do Petróleo, Gás Natural e Biocombustíveis. -Rio de Janeiro : ANP, 2008.

ALTVATER, E. O preço da riqueza: pilhagem ambiental e a nova (des) ordem mundial. São Paulo: UNESP, 1995.

ALIER, Joan Martinez. The environmentalism of the poor - a study of ecological conflicts and valuation. Cheltenham, UK: Edward Elgar, 2002.

ALIER, Joan Martinez. Justiça ambiental e decrescimento econômico: a aliança dos dois movimentos. In: Enfrentando os limites do crescimento: sustentabilidade, decrescimento e prosperidade. Philippe Léna e Elimar Pinheiro do Nascimento (orgs.). Rio de Janeiro: Garamond, 2012.

ALVES, José E. Diniz. Expansão do crédito e crescimento da classe média no Brasil. SCRIBD, 2011.

AMARO, Meiriane Nunes. Produção e Consumo Sustentáveis. Brasília: Senado Federal, 2012.

ARTHUS-BERTRAND, Yann. Documentário Human. Disponível em: $<$ https://humanthemovie.withgoogle.com/intl/pt-br/> Acesso em 10 de setembro de 2015.

BANCO MUNDIAL. DATABANK: Base de Dados do Banco Mundial. 2015.

BARBOSA, Livia. Sociedade de consumo. Rio de Janeiro: J. Zahar, 2004.

BARDIN, Laurence. Análise de conteúdo. Lisboa: Edições 70, 1977.

BAUDRILLARD, Jean. A Sociedade de Consumo. Lisboa: Edições 70, 1991.

BAUMAN, Zygmunt. Vida para consumo: a transformação das pessoas em mercadorias. Rio de Janeiro: Jorge Zahar, 2008.

BAUMAN, Zygmunt. Vida líquida. Rio de Janeiro: Jorge Zahar, 2007. 
BERRÍOS, Manuel Rolando. Reflexões sobre o consumo e o consumismo. In: CORTEZ, Ana Tereza Cáceres; ORTIGOZA, Sílvia Aparecida Guarnieri (Orgs). Consumo Sustentável: conflitos entre necessidade e desperdício. São Paulo: Unesp, 2007.

BIELSCHOWSKY, Ricardo. Estratégia de desenvolvimento e as três frentes de expansão no Brasil: um desenho conceitual. Economia e Sociedade, v.21, Campinas, 2012.

BONAIUIT, Mauro. A caminho da grande transição. In: Enfrentando os limites do crescimento: sustentabilidade, decrescimento e prosperidade. Philippe Léna e Elimar Pinheiro do Nascimento (orgs.). Rio de Janeiro: Garamond, 2012.

BOSCHI, Renato; GAITÁN, Flavio. Intervencionismo estatal e políticas de desenvolvimento na América Latina. Caderno CRH, Salvador, v.21, n.53, p. 305-322, 2008.

BOURDIEU, Pierre. A distinção: crítica social do julgamento. São Paulo: Edusp; Porto Alegre-RS: Zouk, 2007.

BRASIL. Ministério das Cidades/Secretaria de Assuntos Estratégicos da Presidência da República. Pesquisa de satisfação dos beneficiários do Programa Minha Casa Minha Vida/editado por Fernando Garcia de Freitas e Érica Negreiros de Camargo Brasília, DF: MCIDADES; SNH; SAE-PR; IPEA, 2014.

BRASIL. Plano de Ação para Produção e Consumo Sustentáveis. 2011.

BRASIL. Consumo Sustentável: Manual de educação. Brasília: Consumers International/ MMA/ MEC/IDEC, 2005. $160 \mathrm{p}$.

BRUM, Andréia Barreto do Nascimento; HILLIG, Clayton. Repensando o consumismo: uma reflexão sobre a necessidade de um "consumo responsável". Revista Eletrônica em Gestão, Educação e Tecnologia Ambiental, v. 01, no 01, p. 115-128, 2010.

BUARQUE, Cristovam. A desordem do progresso: $O$ fim da era dos economistas e a construção do futuro. 4. ed.,Rio de Janeiro: Paz e Terra, 1993.

CAMARGO, Ana Luiza do Brasil. Desenvolvimento sustentável: dimensões e desafios. Campinas: Papirus, 2003.

CASTAÑEDA, Marcelo. Teorias das práticas na análise do consumo. Ciências Sociais Unisinos, São Leopoldo - RS, v. 46, n. 3, p. 248-255, 2010.

CAVALCANTI, Clóvis (Org.). Meio ambiente, desenvolvimento sustentável e políticas públicas. 4.ed. São Paulo: Cortez, 2002. 
COHEN, Maurie.; MURPHY, Joseph. Exploring sustainable consumption: environmental policy and the social sciences. Oxford: Elsevier Science, 2001.

CORTEZ, Ana Tereza Cáceres; ORTIGOZA, Sílvia Aparecida Guarnieri (Orgs). Consumo Sustentável: conflitos entre necessidade e desperdício. São Paulo: Unesp, 2007.

COSTA, Lucio Augusto Villela da; IGNÁCIO, Rozane Pereira. Relações de consumo x meio ambiente: Em busca do desenvolvimento sustentável. In: Âmbito Jurídico, Rio Grande, XIV, n. 95, 2011.

COSTA, Humberto; TUTIDA, Daniel Kendi Anghinoni; MACHADO, Juliano Miranda; NUNES, Rosangela Somavilla. A sustentabilidade endossando o consumismo contemporâneo: uma reflexão crítica. Revista Percurso, v. 14 no 01, 2014.

DESLAURIERS, J. P. Pesquisa Qualitativa: Guia prático. Montreal: McGrawHill Éditeurs, 1991.

DINATO, Monique Revillion; NASCIMENTO, Luis Felipe. Consumo sustentável e o Sistema Produto-Serviço: reflexões para um outro desenvolvimento. ENANPAD, 2003.

DUARTE, Rosália. Pesquisa Qualitativa: reflexões sobre o trabalho de campo. Cadernos de Pesquisa, n. 115, p. 139-154, 2002.

EDDINE, Siomara Cador; VETTORAZZI, Karlo Messa; FREITAS, Vladimir Passos de. Consumo e sustentabilidade: desafios para uma nova atitude ecológica. XVII Congresso Nacional do CONPEDI, Brasília, 2008.

ENRÍQUEZ, Maria Amélia. Trajetórias do desenvolvimento: da ilusão do crescimento ao imperativo da sustentabilidade. Rio de Janeiro: Garamond, 2010.

FLICK, Uwe. Desenho da pesquisa qualitativa. Porto Alegre: Artmed, 2009.

FURTADO, Celso. O mito de desenvolvimento econômico. Rio de Janeiro: Paz e Terra, 1974.

GREENPEACE. Desmatamento: a falta de água começa aqui. Disponível em: $<$ http://www.greenpeace.org/brasil/pt/Noticias/Desmatamento-A-falta-de-agua-comecaaqui/> Acesso em: 30 de setembro de 2015.

GIL, A .C. Métodos e técnicas de pesquisa social. 5.ed. São Paulo: Atlas, 1999.

GODOY, Arilda Schmidt. Pesquisa Qualitativa: tipos fundamentais. Revista de Administração de Empresas. São Paulo, v. 35, n. 3, 1995. 
GOKENE, Marcos Vinicius; NAIME, Roberto Harb; FIGUEIREDO, João Alcione Sganderla. O consumismo e a geração de resíduos sólidos urbanos no Brasil. Rev. Elet. em Gestão, Educação e Tecnologia Ambiental, v(8), no 8, p. 1700-1712, set-dez, 2012.

GUIMARÃES, Gabriella Casimiro. Consumo sustentável para a minimização de resíduos sólidos urbanos. Dissertação de Mestrado, Universidade de Brasília, Brasília, 2011.

HEIDEMANN, Francisco G. Do sonho do progresso às políticas de desenvolvimento. In: HEIDEMANN, F. G. e SALM, J. F (Org.). Políticas públicas e desenvolvimento: bases epistemológicas e modelos de análise. Brasília: Editora Universidade de Brasília, 2009.

HERCULANO, Selene Carvalho. Do desenvolvimento (in)suportável à sociedade feliz. In: GOLDENBERG, Mirian (Coord.). Ecologia, ciência e política. Rio de Janeiro: REVAN, 1992. p. 9 - 48

HOPWOOD, Bill; MELLOR, Mary; O’BRIEN, Geoff. Sustainable Development: mapping diferrent approaches. Sustainable Development, v. 13, 2005, pp. 38-52.

INSTITUTO DE PESQUISA EM ECONOMIA APLICADA (IPEA). IPEADATA: Banco de Dados do Instituto de Pesquisa em Economia Aplicada. Macroeconômico. 2015.

LATOUCHE, Serge. O decrescimento, por que e como? In: Enfrentando os limites do crescimento: sustentabilidade, decrescimento e prosperidade. Philippe Léna e Elimar Pinheiro do Nascimento (orgs.). Rio de Janeiro: Garamond, 2012.

LEFF, Enrique. Educação ambiental e desenvolvimento sustentável. In REIGOTA, Marcos (org.). Verde cotidiano: o meio ambiente em discussão. Rio de Janeiro: DP\&A, 1999 (p.111-129).

LOMBARDO, Magda Adelaide. In: CORTEZ, Ana Tereza Cáceres; ORTIGOZA, Sílvia Aparecida Guarnieri (Orgs). Consumo Sustentável: conflitos entre necessidade e desperdício. São Paulo: Unesp, 2007.

MACIEL, Marcela Albuquerque. Políticas públicas e desenvolvimento sustentável: A avaliação ambiental estratégica como instrumento de integração da sustentabilidade ao processo decisório. In: Âmbito Jurídico, Rio Grande, XIV, n. 89, jun 2011.

MADURO-ABREU, Alexandre. Valores, consumo e sustentabilidade. Brasília. 2010. Tese (Doutorado em Desenvolvimento Sustentável) - Universidade de Brasília.

MARTINS, G. A. Estudo de caso: uma estratégia de pesquisa. 2 ed. São Paulo: Atlas, 2008. 
MATIAS, Eduardo Felipe P. A humanidade contra as cordas: a luta da sociedade global pela sustentabilidade. São Paulo: Paz e Terra, 2014.

MARQUES, Cláduia Brazil; SANTOS, Carlos Honorato Schuch. Políticas públicas para pensar no desenvolvimento de um sítio local - um modelo. Revista Portuguesa de Estudos, n.25/26, 2011.

MINISTÉRIO DA CIÊNCIA, TECNOLOGIA E INOVAÇÃO. Estratégia Nacional de Ciência, Tecnologia e Informação. Brasília: MCTI, 2012.

MINISTÉRIO DA CIÊNCIA, TECNOLOGIA E INOVAÇÃO. Livro Azul da 4a Conferência Nacional de Ciência, Tecnologia e Inovação para o Desenvolvimento Sustentável. Brasília: MCTI/Centro de Gestão e Estudos Estratégicos, 2010.

MINISTÉRIO DO PLANEJAMENTO, ORÇAMENTO E GESTÃO. Relatório Anual de Avaliação do PPA 2012-2015: ano base 2013. Brasília: SPI/MP, 2014.

MINISTÉRIO DO PLANEJAMENTO, ORÇAMENTO E GESTÃO. Relatório Anual de Avaliação do PPA 2012-2015: ano base 2014. Brasília: MP, 2015.

MONTIBELLER-FILHO, Gilberto. O mito do desenvolvimento sustentável: meio ambiente e custos sociais no moderno sistema produtor de mercadorias. Florianópolis: Ed. da UFSC, 2001.

MORAIS, Leandro Pereira; COSTA, Adriano B. Ferreira. Por novos Paradigmas de produção e consumo. In: MORAIS Leandro Pereira; BORGES Adriano. Novos paradigmas de produção e consumo: experiências inovadoras, organizadores. São Paulo: Instituto Pólis, 2010. cap. 1, p. 13-19.

NAÇÕES UNIDAS. Declaração do Rio de Janeiro sobre Meio Ambiente e Desenvolvimento. Rio de Janeiro, 1992.

OLIVEIRA, Verônica Macário; CÂNDIDO, Gesinaldo Ataíde; GÓMEZ, Carla Regina Pasa. Contemporaneidade do consumo sustentável e as suas correlações com as políticas públicas, as práticas empresariais e o comportamento do consumidor. IX Encontro Nacional da EcoEco, Brasília, 2011.

ORTIGOZA, Silvia Aparecida Guarnieri. De Consumo Dirigido a Consumo Sustentável: uma abordagem geográfica da questão. IX RCSP, 2003. Rio Claro, São Paulo. Disponível em: $<$ http://www.observatoriogeograficoamericalatina.org.mx/egal9/Geografiasocioeconomi $\mathrm{ca} /$ Geografiaespacial/13.pdf>

PEREIRA, Agostinho Oli Koppe; CALGARO, Cleide. A posição do consumidor na sociedade moderna hiperconsumista: políticas públicas de educação para o consumo sustentável. Revista Fac. Dir. Sul de Minas, Pouso Alegre, v. 28, ํㅡ.2, 2012. 
PORTILHO, Fátima. Sustentabilidade ambiental, consumo e cidadania. São Paulo: Cortez, 2010.

PORTILHO, Fátima. Consumo sustentável: limites e possibilidades de ambientalização e politização das práticas de consumo. Cad. EBAPE.BR, 2005.

PROGRAMA DAS NAÇÕES UNIDAS PARA O DESENVOLVIMENTO. Relatório de Desenvolvimento Humano. Nova York: UNDP, 2014.

PROGRAMA DAS NAÇÕES UNIDAS PARA O MEIO AMBIENTE. Relatório do Índice da Riqueza Inclusiva. Nova York: Cambridge University Press, 2012.

PROGRAMA DAS NAÇÕES UNIDAS PARA O MEIO AMBIENTE. Rumo a uma economia verde: caminhos para o desenvolvimento sustentável e a erradicação da pobreza, 2011.

PROGRAMA DAS NAÇÕES UNIDAS PARA O MEIO AMBIENTE. Processo de Marrakesh. 2003

PUJADAS, C. et al. Consumo Sostenible ante la Crisis Global. Revista de Ciencia Política, Buenos Aires, n. 8, 2009.

RIBEMBOIM, Jacques. Mudando os padrões de produção e consumo urbanos. Congresso da ANPUR. Rio de Janeiro, 2001.

ROTH, Caroline das Graças; GARCIAS, Carlos Mello. A influência dos padrões de consumo na geração de resíduos sólidos dentro do sistema urbano. REDES, Santa Cruz do Sul, v. 13, n. 3, p. $5-13$, set/dez. 2008.

SACHS, Ignacy. Rumo à ecossocioeconomia: teoria e prática do desenvolvimento. Org: Paulo Freire Vieira. São Paulo: Cortez, 2007.

SACHS, Ignacy. Desenvolvimento: includente, sustentável, sustentado. Rio de Janeiro: Garamond, 2008.

SACHS, Ignacy. Caminhos para o Desenvolvimento Sustentável. $3^{a}$ edição. Rio de Janeiro: Garamond, 2009.

SACHS, Ignacy. Ecodesenvolvimento: crescer sem destruir. São Paulo: Vértice, 1986.

SANTÍN ESTEBAN, M. Paz. Pesquisa qualitativa em educação. Porto Alegre: Artmed, 2010.

SCANTIMBURGO, André Luis. Políticas públicas e desenvolvimento sustentável: os limites impostos pelo capitalismo no gerenciamento e preservação dos recursos hídricos no Brasil. Revista Aurora, ano V, №. 7, 2011. 
SEQUINEL, Maria Carmem Mattana; CARON, Antoninho. Consumo sustentável: uma questão educacional e de múltiplas responsabilidades. Revista Brasileira de Ciências Ambientais, n. 16, junho, 2010.

SILVA, Minelle Enéas; BALBINO, Débora Prazeres; GÓMEZ, Carla Pasa. Consumo sustentável na base da pirâmide: definindo papéis e obrigações para a efetivação do desenvolvimento sustentável. Revista de Gestão Social e Ambiental - RGSA, São Paulo, v. 5, n. 2, 2011.

SILVA, Minelle Enéas da. Consumo sustentável: a articulação de um constructo sob a perspectiva do desenvolvimento sustentável. Revista Eletrônica de Ciência Administrativa - RECADM. Porto Alegre, 2012.

SODRÉ, Marcelo Gomes. Padrões de consumo e meio ambiente. In: Comércio e meio ambiente - Direito, economia e política. São Paulo: SMA, 1996.

SOUZA, Amaury de; LAMOUNIER, Bolivar. A Classe Média Brasileira. Ambições, valores e projetos de sociedade. Rio de Janeiro: Elsevier; Brasília, DF: CNI, 2010.

SOUSA, Evangelina da Silva; CARVALHO, Denis Barros de. Educação para gestão ambiental: um estudo dos instrumentos propostos pela administração pública federal voltados ao consumo sustentável. Revbea, São Paulo, v. 10, n. 02, 2015.

SPÍNOLA, Ana Luiza. Consumo sustentável: o alto custo dos produtos que consumimos. Revista de Direito Ambiental. São Paulo, v. 6, n. 24, p. 209-216, out-dez, 2001.

VEBLEN, Thorstein. A teoria da classe ociosa: um estudo econômico das instituições. São Paulo: Pioneira, 1965.

VIEGAS, Daniela. Consumo sustentável e cidadania: reflexões sobre a atuação de empresas, sociedade civil e estado na comunicação para a mobilização socioambiental na realidade de Belo Horizonte. Dissertação de Mestrado. Centro Universitário UNA, 2010.

VOLTOLINI, Ricardo. O impacto da sustentabilidade na percepção das marcas. Idéia Sustentável, $2009 . \quad$ Disponível em: $<$ http://www.ideiasustentavel.com.br/2009/09/livre-pensar-o-impacto-dasustentabilidade-na-percepcao-das-marcas/>

WARDE, Alan. Consumption, Food and Taste: culinary antinomies and commodity culture. London: SAGE Publications, 1997.

YIN, R.K. Estudo de caso: planejamento e métodos. 3. ed. Porto Alegre: Bookman, 2005. 


\section{APÊNDICE A}

Roteiro pré-estabelecido para as entrevistas

1. Cada dia mais a sustentabilidade aparece nas discussões das políticas públicas como um fator relevante para o processo de desenvolvimento do país. Qual a relação entre sustentabilidade e desenvolvimento?

2. Segundo dados oficiais do governo, a estratégia de desenvolvimento do Brasil é aumentar o consumo de massa como base para um processo produtivo. Como as demandas sociais e econômicas vem sendo compatibilizadas no Brasil no seu processo de desenvolvimento, considerando suas políticas públicas orientadoras?

3. Atualmente, existe alguma principal política que o Brasil esteja desenvolvendo com relação a sustentabilidade?

4. Existe algum caminho ideal a ser percorrido pelo país para atingir o desenvolvimento sustentável?

5. Qual a relação entre consumo e meio ambiente nas políticas públicas brasileiras?

6. Para o desenvolvimento sustentável, o Brasil deveria enfrentar a pobreza fazendo uma correta consideração dos custos ambientais envolvidos nesse processo. Existe no governo a ideia de erradicar a pobreza preservando o meio ambiente?

7. Quais tecnologias o Brasil poderia melhorar seu desempenho com relação à sustentabilidade?

8. Como o governo formula sua estratégia de desenvolvimento com base no consumo sustentável?

Programa das Nações Unidas para o Desenvolvimento

1. Para a ONU, o Brasil desempenha um papel importante no processo de construção do desenvolvimento sustentável?

2. Qual a sua avaliação da participação do Brasil na articulação da nova agenda de desenvolvimento sustentável?

3. O que esperar do Brasil na efetivação dos Objetivos de Desenvolvimento Sustentável?

4. Existe alguma parceria entre a ONU e o governo brasileiro que impacte positivamente no alcance do desenvolvimento sustentável? 


\section{Ministério das Relações Exteriores}

1. Nas negociações da nova agenda de desenvolvimento sustentável da ONU, a questão do consumo era uma preocupação para o Brasil?

2. Qual a sua avaliação da participação do Brasil no processo de elaboração da agenda 2030?

3. Com relação aos Objetivos de Desenvolvimento Sustentável, quais o país pode obter melhores resultados? O que esperar do Brasil na efetivação dos ODS?

Ministério do Planejamento, Orçamento e Gestão

1. Como o Programa de Aceleração do Crescimento contribui para o desenvolvimento do país do ponto de vista ambiental?

2. Quando o Programa de Aceleração do Crescimento é criado existe articulação com o Ministério do Meio Ambiente para que ocorra um acompanhamento do ponto de vista ambiental?

3. Qual a relevância do meio ambiente para o Programa de Aceleração do Crescimento?

Ministério do Meio Ambiente

1. Há articulação dos outros ministérios com o Ministério do Meio Ambiente sempre que formulam alguma política pública que possa impactar no meio ambiente?

2. A questão do consumo e a criação do Plano de Ação para Produção e Consumo Sustentáveis pode ser considerada como principal para uma nova estratégia de desenvolvimento sustentável?

3. O Plano de Ação para Produção e Consumo Sustentáveis vem agradando o governo em seus resultados?

4. Com relação ao desmatamento, o Brasil está preparado para lidar mais fortemente com a questão e evitar que mais desmatamentos ocorram?

Ministério da Ciência, Tecnologia e Informação

1. Qual a relevâncias das questões ambientais para a Estratégia Nacional de Ciência, Tecnologia e Inovação?

2. Como a Estratégia Nacional de Ciência, Tecnologia e Inovação ajuda o Brasil a 
enfrentar o desafio da pobreza sem prejudicar o meio ambiente?

3. Como a Estratégia Nacional de Ciência, Tecnologia e Inovação colabora para a compreensão da relação entre consumo e meio ambiente?

4. O Brasil está propondo ou elaborando alguma inovação para a questão ambiental?

5. A Estratégia Nacional de Ciência, Tecnologia e Inovação pode contornar a defasagem de ciência e tecnologia do Brasil com as nações mais desenvolvidas?

6. Como a Estratégia Nacional de Ciência, Tecnologia e Inovação pode ajudar a expandir a liderança brasileira na questão do desenvolvimento sustentável? 